This manuscript is an EarthArXiv preprint and has not yet been peer reviewed. A version of it is currently in review at Communications Earth \& Environment. Future versions may have slightly different content.

\title{
Supraglacial debris thickness and supply rate in High-Mountain Asia
}

\author{
Michael McCarthy ${ }^{*}{ }^{1,2}$, Evan Miles ${ }^{1}$, Marin Kneib ${ }^{1,3}$, Pascal Buri ${ }^{1}$, Stefan Fugger ${ }^{1,3}$, \\ Francesca Pellicciotti ${ }^{1,4}$ \\ Correspondence to: michael.mccarthy@wsl.ch \\ 1. Swiss Federal Research Institute WSL, Birmensdorf, Switzerland \\ 2. British Antarctic Survey, Natural Environment Research Council, Cambridge, UK \\ 3. Institute of Environmental Engineering, ETH Zurich, Zurich, Switzerland \\ 4. Department of Geography, Northumbria University, Newcastle, UK
}

December 3, 2021 


\section{s Abstract}

6 Supraglacial debris strongly modulates glacier melt rates and can be decisive for ice dynamics and mountain hydrology. It is ubiquitous in High-Mountain Asia (HMA), yet because its thickness and supply rate from local topography are poorly known, our ability to forecast regional glacier change and streamflow is limited. Here we resolved the spatial distribution of supraglacial debris thickness (SDT) for 4401 glaciers in HMA

\section{Introduction}

Supraglacial debris exists on $7.3 \%$ of Earth's mountain glacier surfaces [1] and is increasing in areal extent in many mountain ranges due to recent climatic warming [2-9]. It can strongly modify the glacier-surface energy balance, enhancing or reducing the melt rate of the ice it overlies depending on its thickness [10, 11]. As such, the dynamic and hydrological responses of debris-covered glaciers can be strikingly different from those of debris-free glaciers to similar climatic forcing [12-14]. Debris-covered glaciers tend to have long, low-gradient tongues with low surface velocity and stable termini $[15,16]$, and inefficient drainage systems which cause runoff to be delayed $[17,18]$.

In High-Mountain Asia (HMA), where large populations and unique mountain ecosystems are dependent on glacier-derived runoff [19-22] and 8.3 to $12 \%$ of glacier area is debris covered [1, 23, 24], it is essential to be able to accurately predict glacier change. However, models of the region's glaciers have either ignored the effects of supraglacial debris or dealt with them in a simplified manner [23, 25]. This is because two key model inputs, supraglacial debris thickness (SDT) and debris-supply rate (DSR), the second of which is likely to be an important control on SDT and supraglacial debris extent, are either lacking or poorly constrained at the regional scale.

In-situ measurements of SDT have been made at only $\sim 28$ of the largely inaccessible 95 thousand glaciers of HMA (Supplementary Table 1), often with sparse and biased spatial coverage. Remote-sensing estimates have been made at a range of spatial scales [23, 26-32] but at larger scales mainly from debris surface temperature, which can demonstrate a complex and sometimes insensitive response to SDT [33]. Headwall-erosion rate has been measured at point locations for $\sim 19$ glaciers (Supplementary Table 2), mostly in the northwestern Himalaya e.g. [34, 35], while DSR, which we distinguish from headwall-erosion rate as the rate at which debris is eroded from a glacier's debris-supply slopes and reaches its surface, has been estimated at only eight glaciers using debris mass-balance models, so is mostly unknown [36-38]. 
To secure widespread, systematic coverage of SDT and DSR in HMA, and thus facilitate advances in our understanding of the role of debris in the evolution of the region's glaciers, we generated highly resolved, regionally consistent datasets of both variables comprising 4401 and 3843 individual glaciers respectively, deriving SDT from glacier mass balance, which typically shows strong sensitivity to SDT e.g. [39]. In the process, we calculated englacial debris content, which has only been measured at three glaciers in HMA [38, 40-42], supraglacial debris volume and debris-supply-slope area. We carried out a rigorous uncertainty assessment and validated our datasets using all available in-situ data, then used them to disentangle the factors that regulate supraglacial debris supply, occurrence and distribution.

\section{Supraglacial debris thickness and volume}

We calculated SDT for the 4401 study glaciers for the period 2000-2016 (Figure 1a), via a specific mass balance (SMB)-inversion approach. Forcing an energy-balance model of the debris surface with downscaled ERA5-Land reanalysis data, we derived the physical relationship between SDT and SMB independently for each $100 \mathrm{~m}$ of elevation of each glacier, then inverted those relationships leveraging a new dataset of altitudinally-resolved SMB [43]. Using Monte Carlo simulations, we propagated source uncertainties to our results (Methods). Our modelled SDT data agree closely with in-situ SDT data at 13 validation sites in terms of altitudinal pattern and central value per glacier (Figure 1a; Supplementary Figures 1-15).

There is strong spatial variability in SDT both regionally and locally (Figure 1a), with most glaciers showing a wide internal range. There is an overall skew towards thin debris $(54 \%<0.1 \mathrm{~m})$, and relatively little thick debris $(9.0 \% \geq 0.9 \mathrm{~m})$, with thinner debris concentrated at higher elevations up-glacier due to recent exhumation from the ice, where fractionally little debris cover exists (Figure 1b; Figure 1a subplots). Thicker debris is concentrated at lower elevations down-glacier due to a slowing conveyor-belt effect [44], where large moraines often exist, and where debris cover is more extensive. Mean SDT for the study glaciers (representing $54 \%$ of total debris-covered glacier area) is $0.34_{-0.21}^{+0.51} \mathrm{~m}$ (Figure 1c), which corresponds to a regional debris volume of $1.54_{-0.94}^{+2.32} \mathrm{~km}^{3}$, given an observed debris-covered glacier area of 33 thousand $\mathrm{km}^{2}$. Median SDT is considerably lower at $0.08 \mathrm{~m}$.

Importantly, we found that glaciers in an advanced stage of their debris-cover evolution [1] and whose surfaces are fractionally more debris covered overall, have higher mean SDT (Figures 1d and 1e) and therefore carry more debris per area-something that has long been hypothesised, but never before borne out by data. This is consistent with the notion that supraglacial debris thickens as glaciers lose mass, exhuming more debris to their surfaces from within [45, 46], and implies that supraglacial debris will thicken further in HMA in response to the warming climate indicated by current scenarios [47].

Surprisingly, given that the debris-covered fractions of glacier areas in these subregions are low, SDT is greatest in the the Kunlun Shan and Inner Tibetan Plateau (Table 1). We hypothesise that this is because i) the minimal debris cover in these subregions (6.2 and 5.6\% respectively) occurs close to the glacier margins where debris tends to be thick, and ii) temporal inconsistencies between glacier and debris-cover outlines (we used data from [48] and [24]) mean some non- or formerly-glacierised areas, which exhibit no SMB signal-which would normally be indicative of thick debris-are identified as glacierised [43]. Otherwise SDT is greatest in the Everest and Bhutan subregions of the southeastern Himalaya, where debris stage is advanced and fractional debris-covered 

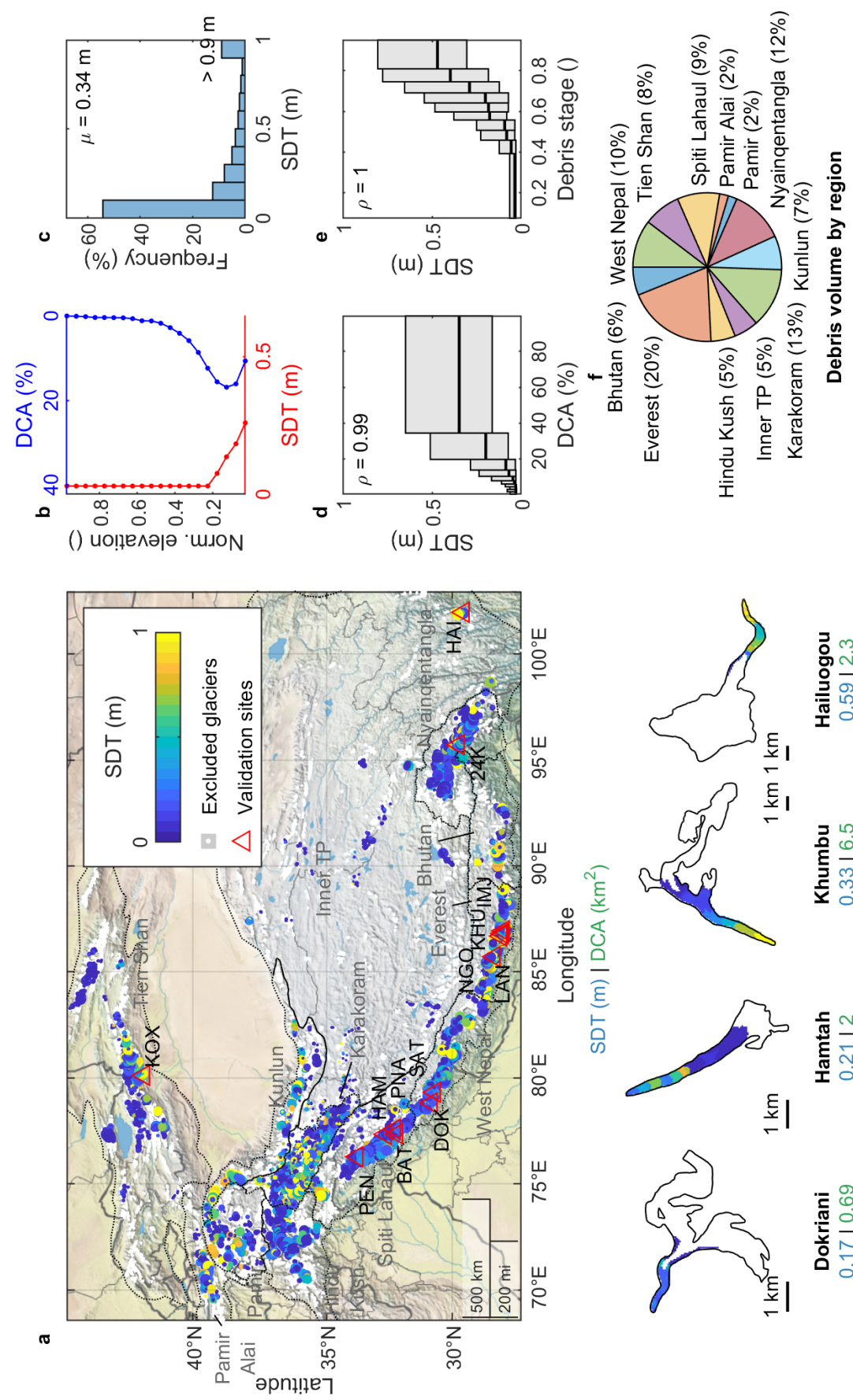

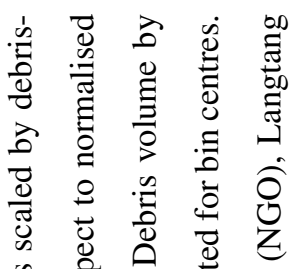

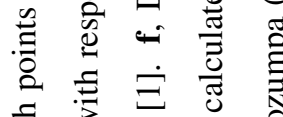

站

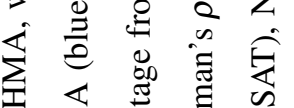

के

ठั

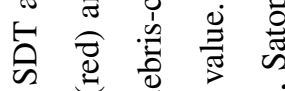

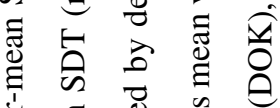

离兽

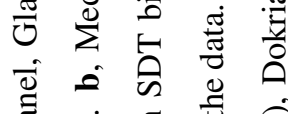

芫

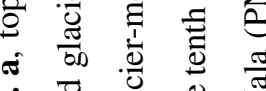

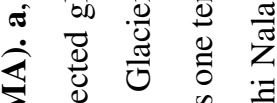

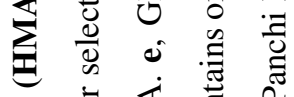

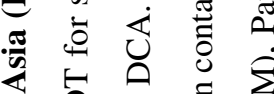

等会合

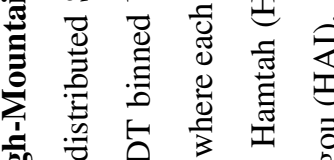
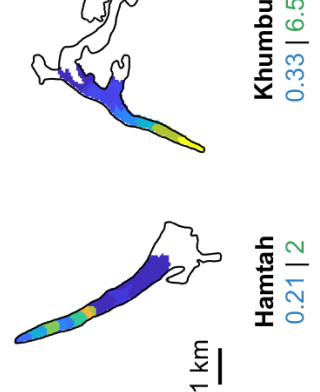

$\int \sqrt[3]{2}$

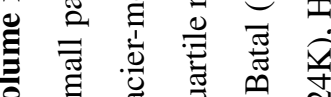

㝵

है

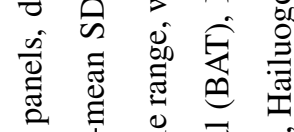

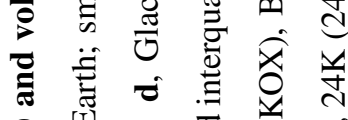

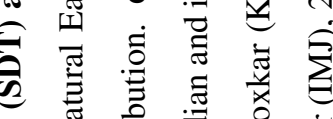

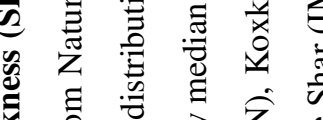

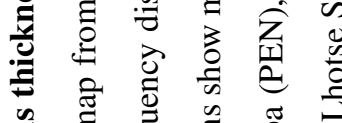

至

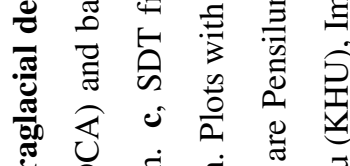

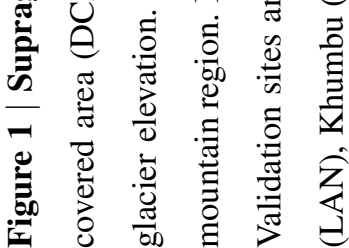


area is high. Considering total glacier area, supraglacial debris is most concentrated in the Everest and Bhutan subregions and least concentrated in the Tien Shan and on the Inner Tibetan Plateau (Supplementary Figure 16).

\section{Debris-supply rate and englacial debris content}

We estimated DSR as a mean terrain-perpendicular value for the debris-supply slopes of 3843 study glaciers by calculating the volume flux of englacial debris to the glacier surface using our SDT results and observed glacier surface velocities [49], then calculating debris-supply-slope area and solving a mass-balance equation such that the mass of debris being eroded from the debris-supply slopes was equal to the mass of debris emerging at the glacier surface [36, 37] (Methods). In doing this we calculated volume fluxes of surface debris and englacial debris content (Methods), and assumed that material eroded by each glacier from its bed [50] stays there [34].

Our results show that DSR is strongly skewed towards lower values and varies over orders of magnitude between glaciers $\left(16-84\right.$ th percentile $=0.0012-0.24 \mathrm{~mm} \mathrm{yr}^{-1}$, median $=0.021 \mathrm{~mm} \mathrm{yr}^{-1}$; Figures $2 \mathrm{a}$ and $\left.2 \mathrm{c}\right)$, the latter of which we attribute to the high climatic, topographic and geologic variability of the HMA region. Interestingly, they show that DSR decreases with distance northwards of the Main Central Thrust (MCT), by approximately an order of magnitude over $\sim 100 \mathrm{~km}$, corroborating at mountain-range scale the observation of [35] for the headwall-

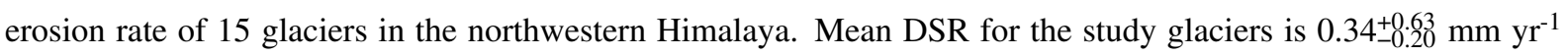
(Figure 2c; Table 2) which, given an observed terrain-perpendicular debris-supply-slope area of 26 thousand $\mathrm{km}^{2}$, corresponds to a volume rate of eroded rock of approximately 910 thousand $\mathrm{m}^{3} \mathrm{yr}^{-1}$.

Importantly, our values of DSR are only around 4\%, on average, of headwall-erosion rates estimated using

${ }^{10} \mathrm{Be}$ cosmogenic nuclides (Supplementary Figure 18). We assert that this is primarily because erosion is strongly episodic and, while cosmogenic nuclides capture erosive processes on a timescale of $\sim 10$ thousand years [51], our debris mass-balance model captures glacier mass-turnover on centennial timescales [52]. On this basis, it's remarkable that we observe a correlation for the small subset of glaciers in our dataset at which cosmogenic nuclide measurements have been made (Supplementary Figure 18), and we note that our short-term estimates of DSR may be more appropriate than longer-term estimates for modelling glacier change on human timescales. Our DSR estimates are similar to previous estimates for six glaciers in HMA which were also made using a debris mass-balance model but based on in-situ data [37] (Supplementary Figure 17). This is good validation of our automated approach, which allowed us to achieve such a large sample size.

We found that englacial debris content has a mean value of $0.19_{-0.13}^{+0.29}$ by ice volume over HMA but is also highly variable between glaciers and skewed low (median $=0.01 \%)$. Our estimates are similar to literature values for bulk glacier ice globally, in the few places it has been measured, but are considerably smaller than for basal ice, where englacial debris tends to be concentrated (Figure 2f; Supplementary Table 3). We estimated a bulk value for Khumbu Glacier, Nepal, of $0.023_{-0.0023}^{+0.15} \%$, which is consistent with the valuable but localised measurements of [40] (Figure 2a), who derived bulk values of $0.1-0.7 \%$ in active areas of the debris-covered part of Khumbu Glacier, Nepal, but $6.4 \%$ in ice near the terminus, which should be expected to show values that are similar to basal ice.

Mean terrain-perpendicular debris-supply-slope area is $6.8 \mathrm{~km}^{2}$ (Figure 2e; Table 2), compared to a mean glacier area of $7.8 \mathrm{~km}^{2}$, and interestingly the debris-supply slopes of most glaciers exist largely within their own elevation ranges (Figure 2b). Volume fluxes of supraglacial debris down-glacier (Figure 2b) increase to a point 


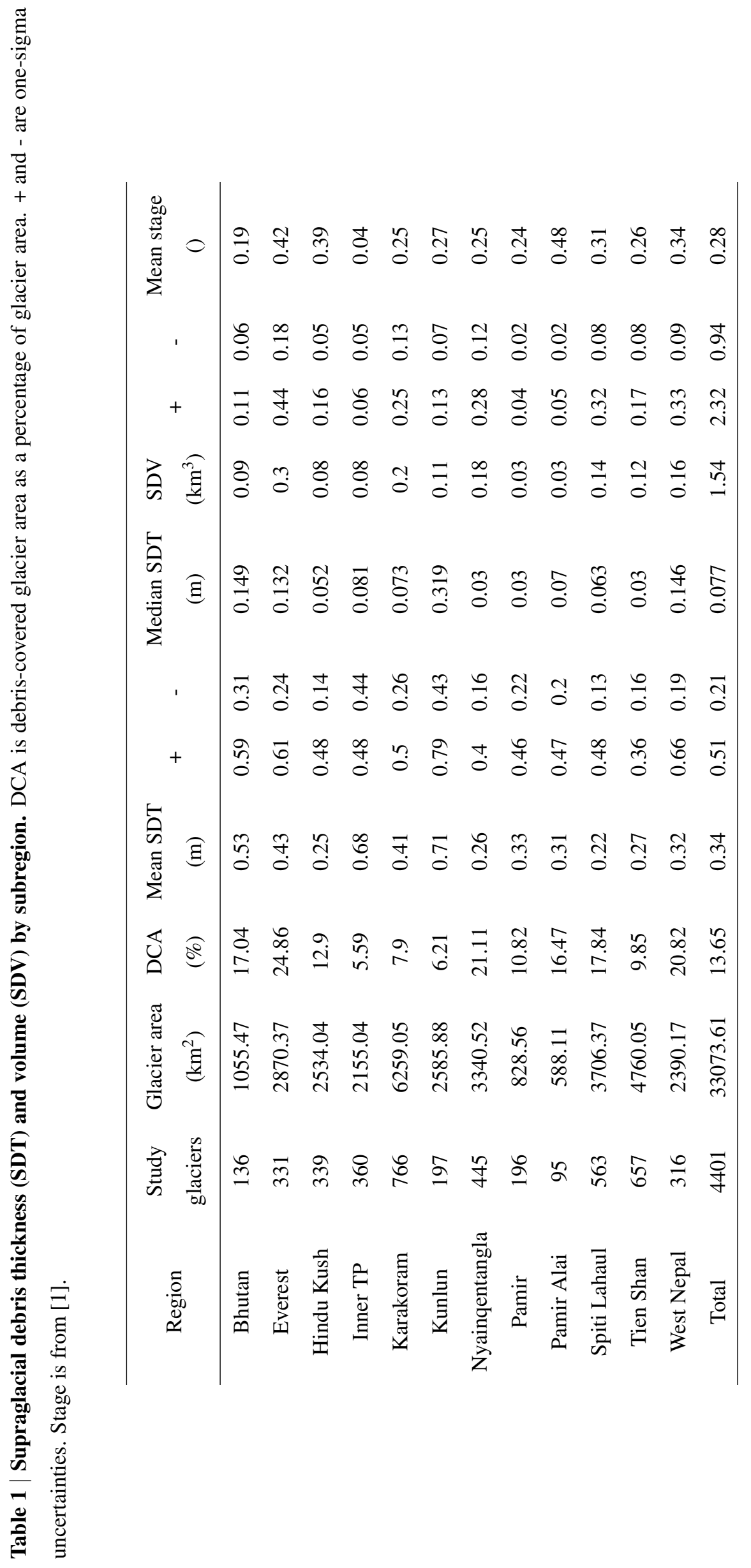



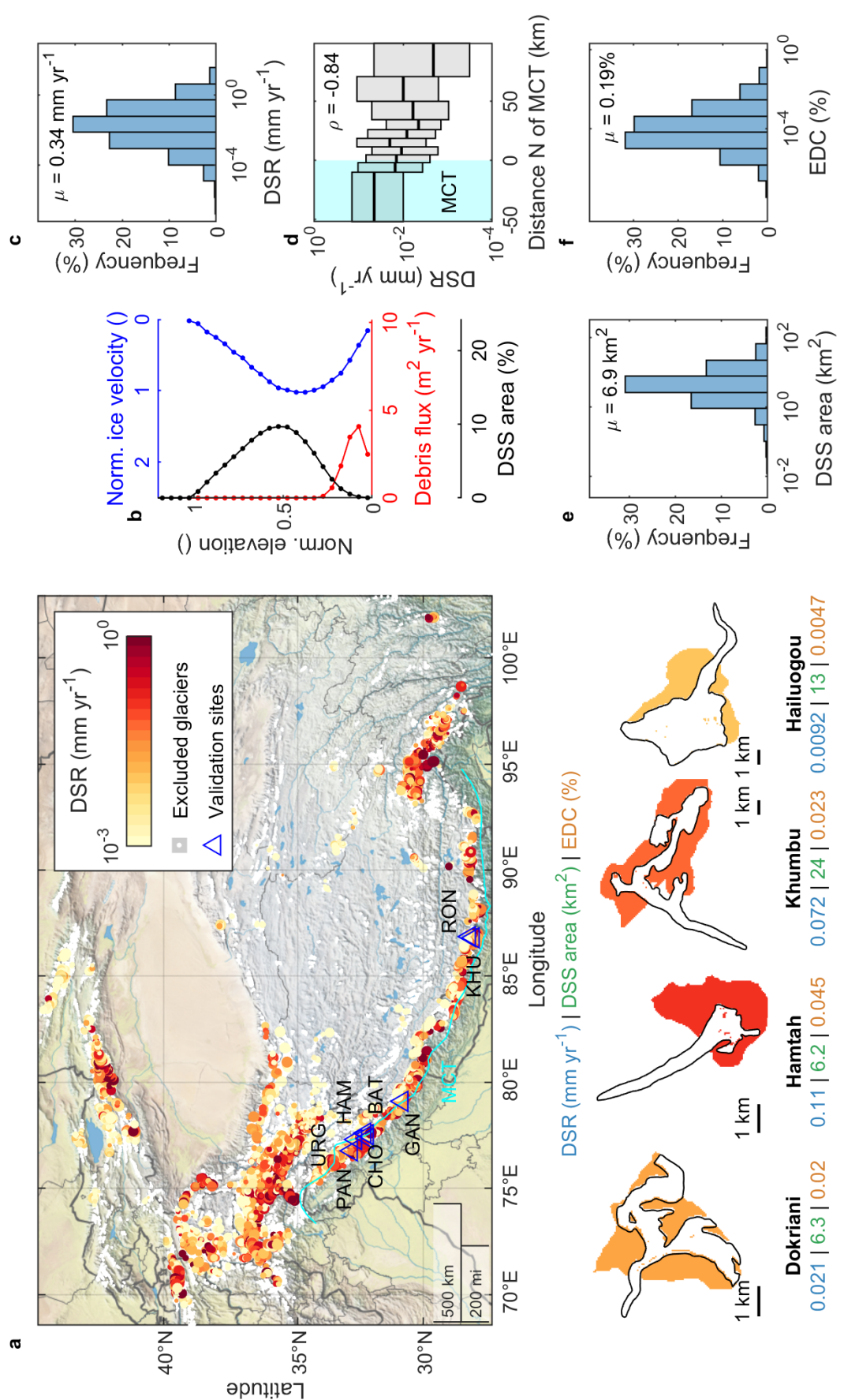

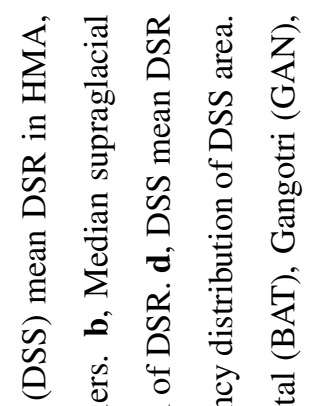

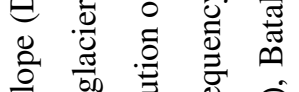

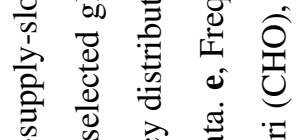

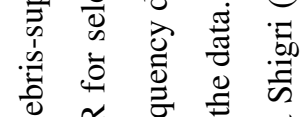

苍苍总氙

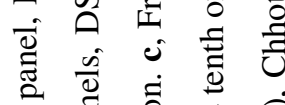

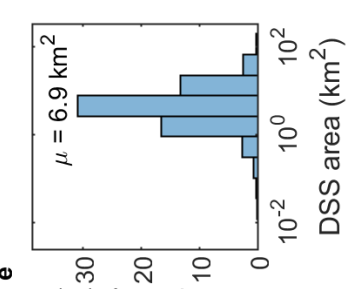

(\%) 人ังuənbəد」

浔 苛

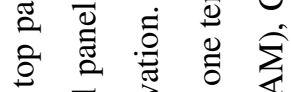

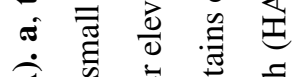

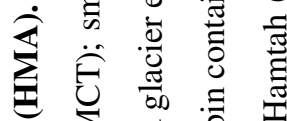

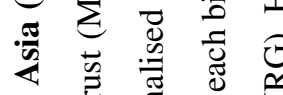

䒮

$\sum_{i}^{0} \tilde{0}_{0}^{0} \tilde{0}$

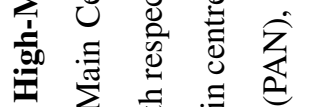

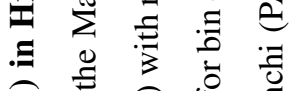

ปิ)

될 全

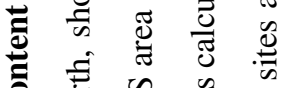

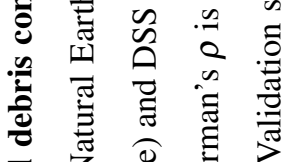

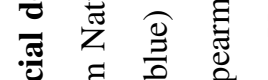

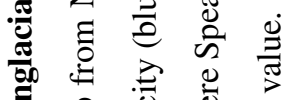

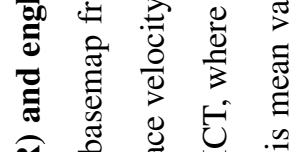

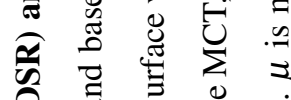

气

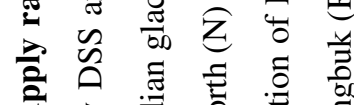

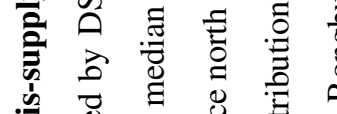

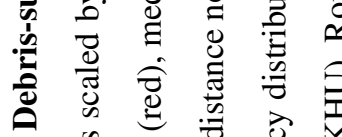

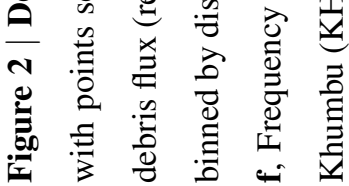


near the terminus as SDT increases, before decreasing to the terminus after ice flow becomes negligible. Despite the fact that we define debris-supply slopes in a different way, our debris-supply-slope areas deviate only slightly from those in the literature and show good agreement overall (Supplementary Figure 19).

Subregionally, DSR and englacial debris content are highest in the Pamir Alai (Table 2), while the Hindu Kush has the largest debris-supply slopes compared to glacier area.

\section{Controls on the glacier-debris system}

Exploiting the 1-km WorldClim 2 climatologies for 1970-2000 [53], we found that DSR increases exponentially with debris-supply-slope mean annual air temperature (MAAT) and stepwise with annual precipitation (Figure 3a and 3b). In the case of MAAT, our results show that the results of [37] for six glaciers in the Himalaya hold over the whole of HMA. In both cases the relationship is likely causal. We found that DSR is highest at MAAT > 7 ${ }^{\circ} \mathrm{C}$, within the range -8 to $-3{ }^{\circ} \mathrm{C}$ in which frost cracking-the dominant process by which physical erosion occurs in cold environments-is particularly efficient $[54,55]$. We suggest that increasing precipitation may increase DSR by increasing the availability of the water necessary for the ice growth that occurs as part of the frost-cracking process [56]. However, we expect that in some cases increasing precipitation will reduce DSR, as snow cover can act to insulate underlying rock surfaces [57].

DSR increases additionally with the slope of the debris-supply slopes and is weakly higher from slopes of south-facing aspect (Figure 3c and 3d). Slope will affect DSR via gravitational redistribution and landsliding in particular, which is more frequent on steeper slopes [58]. Indeed, landsliding is particularly prevalent on slopes steeper than $30^{\circ}$ [59], around which we found strong increases in DSR. Aspect, meanwhile, may exert a control on DSR via incoming shortwave radiation. South-facing slopes are likely to experience larger diurnal temperature variations due to high incoming shortwave radiation receipts during the day and therefore i) pass more often through the frost-cracking window [60], and ii) undergo increased cyclic thermal stressing due to rock expansion and contraction [61].

We found no clear relationship between DSR and major rock types as given by the global lithological map GLiM [62] (Figure 3e), which is likely a reflection of the fact that at large spatial scales, rock-mass strength is governed rather by the spatial frequency of structural geological discontinuities such as joints and faults [63]. Indeed, as discussed above, we found that DSR is higher near the MCT-the major fault at the interface of the Indian and Eurasian tectonic plates (Figure 2d).

Over long timescales, the englacial debris content of a glacier should closely correspond to its debris-ice supply ratio, which is the debris supply to the glacier via erosion divided by the ice supply to the glacier via snowfall. The debris mass-balance model we used to calculate englacial debris content leads to an increase in englacial debris content with glacier-mean SDT and debris-cover stage [1] (Figure 3h and 3i), in-line with the idea that debris-ice supply ratio is a control on the extent to which a glacier becomes debris covered [64]. A high (low) debris-ice supply ratio or englacial debris content will tend to produce an extensively (minimally) debris-covered glacier with thick (thin) debris, although this will depend also on the efficiency of debris transport from the glacier by the glacifluvial system. This complements the finding of a previous study that glaciers with large debris-supply slopes tend to have large debris-covered areas [65]. 


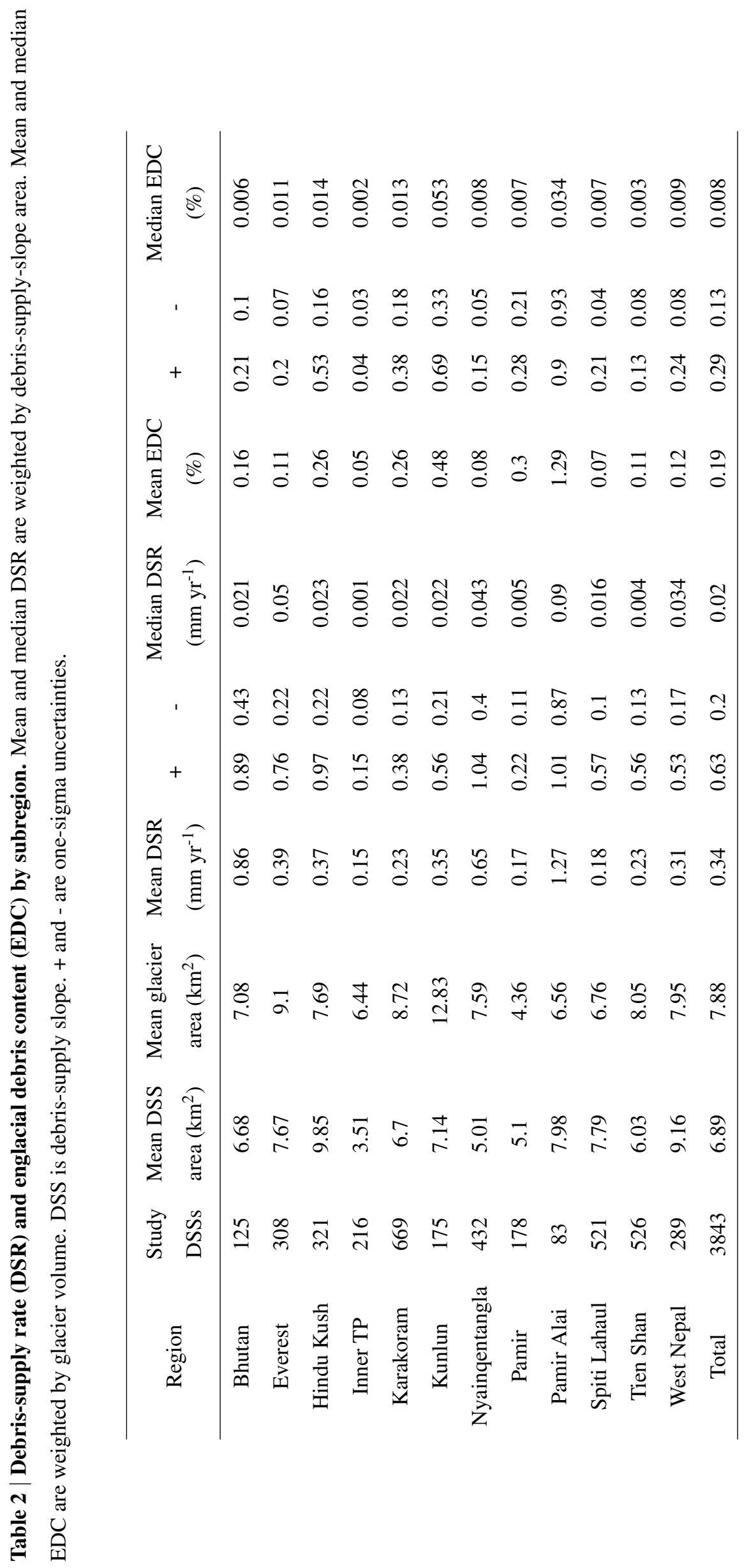




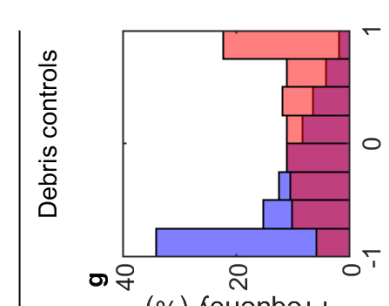

(\%) אัN

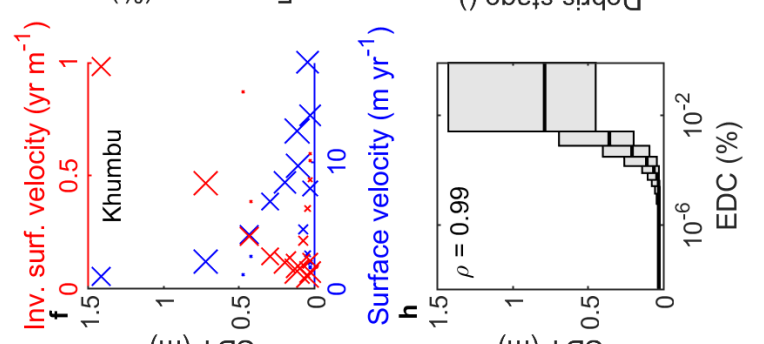

(w) $10 S$

(w) $\perp \mathrm{aS}$

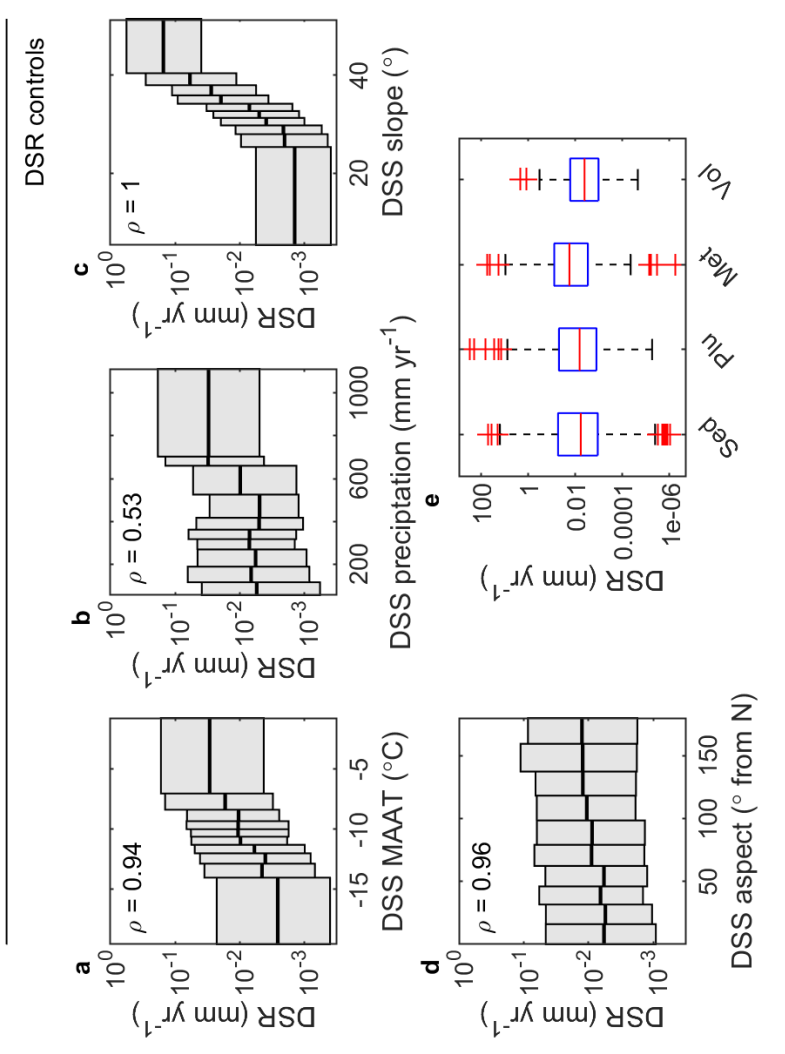

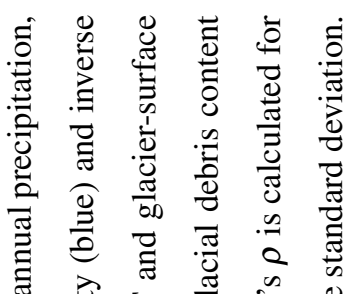

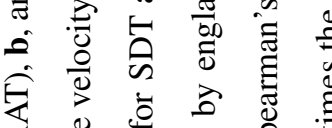

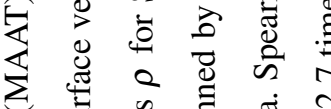

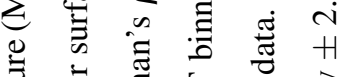

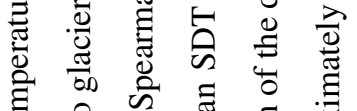

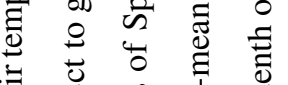

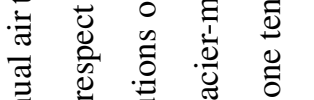

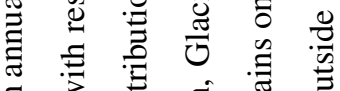

ส $5: 5=$

Ð

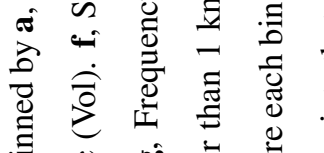

言.

㐘 离

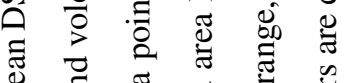

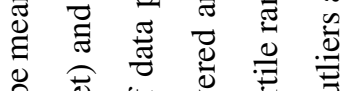

苍

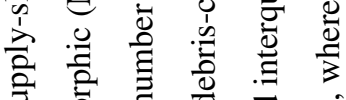

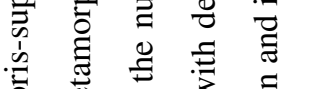

竞焉

它苍苛

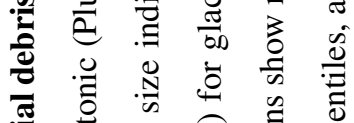

焉泀苛

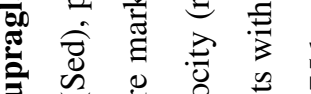

言造

焉

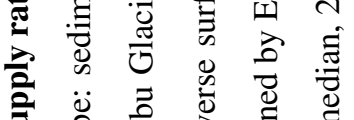

言 芯芯离泀

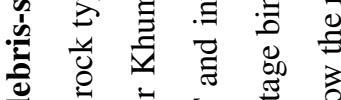

ป

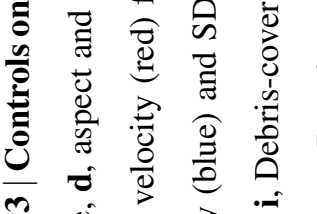

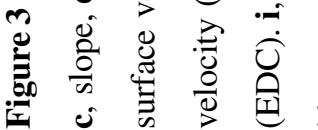


Finally, for glaciers in HMA with a debris-covered area larger than $1 \mathrm{~km}^{2}$, we found that SDT is typically positively correlated with the inverse of the surface velocity (Figure $3 \mathrm{f}$ and $3 \mathrm{~g}$ ). Where surface velocity is low (high), SDT tends to be great (small). This is in agreement with the theory for glaciers whose debris is in steady state [44] and indicates that, while debris-ice supply ratio via englacial debris content governs SDT and supraglacial debris volume at the glacier scale, ice flow modulates the spatial distribution of these variables locally.

\section{Implications for water and sediment supply}

We have quantified SDT, DSR and englacial debris content across HMA, and shown that each is highly spatially variable. Moreover, we have shown that DSR increases robustly with debris-supply-slope MAAT, annual precipitation, slope, aspect from north, and proximity to the MCT, while SDT increases with englacial debris content and the inverse of glacier surface velocity. This is valuable information because the amount, location and movement of debris within a glacier-debris system can strongly influence both the evolutionary trajectory of the glacier(s) in that system [14, 16, 34, 66], and the downstream transport of sediment from it [64]. Crucially, while previous studies have produced vital data for spatial representation of supraglacial debris in glacier models [1, 24, 31, 32], our data and findings pave the way additionally to more sophisticated temporal representation of debris in combined glacier-landscape evolution models [34, 66].

Given the importance of characterising future water supply in HMA-a highly-populated mountain region with rapidly increasing water demand [20]-and the recent boom in the region's hydropower sector [67], the development of such models for application at large spatial scales should be a key direction for future research-an endeavour for which the episodicity of debris supply will be a particular challenge. In a warming climate, documented increases in SDT and debris-covered glacier area in HMA $[2-9,68]$ could intensify in a highly localised and non-linear way due to increased melt-out of englacial debris and debris supply, substantially impacting glacier SMB and runoff. Combined with likely increases in moraine collapse and rockwall debuttressing due to glacier retreat [69], and increases in subglacial erosion due to increases in basal sliding [50], these processes could in turn boost proglacial sedimentation and suspended sediment concentration in rivers. 


\section{Methods}

\section{Calculating supraglacial debris thickness and volume}

We calculated SDT by generating a series of Østrem curves [10] for each glacier using a debris-surface energybalance model, then inverting these Østrem curves using 'measured' SMB data from [43]. This process is described by the flow chart in Supplementary Figure 20, and builds on the work of [28, 70, 71]. We generated the Østrem curves in a Monte Carlo simulation setup with 100 simulations for each $100 \mathrm{~m}$ of glacier elevation. In each simulation, we assigned an SDT value, along with values of key model parameters and variables (Supplementary Table 4), to a random point on the glacier surface. We then ran the model, forcing it with data from the forcing dataset, described below, and recorded the resulting 'modelled' SMB value. After all the simulations had finished, we fitted, to the assigned SDT and modelled SMB values, Østrem curves of a rational form [14]:

$$
b=c_{1} \frac{c_{2}}{h_{s d}+c_{2}}
$$

where $b$ is yearly SMB, $c_{1}$ and $c_{2}$ are free parameters and $h_{s d}$ is SDT (Supplementary Figure 21). To prevent unrealistic Østrem curves, we imposed $c_{1}>-12$ and $<0$ and $c_{2}>0$, and discarded curves with $\mathrm{r}^{2}<0.4$, filling any resulting gaps by linear interpolation. Because the physics of debris-surface energy-balance models is often poor when SDT is very small [72], and ice melt is negligible when SDT is great, we imposed SDT $\geq 0.03 \mathrm{~m}$ and $\leq 5 \mathrm{~m}$. We neglected to account for supraglacial ponds and ice cliffs, which have been shown to be able to cause or exhibit high ice-melt rates on debris-covered glaciers $[73,74]$, so our calculated SDT values are effective rather than absolute. The units of all variables are provided in Supplementary Table 5.

The debris-surface energy-balance model we used bears similarities to those of [75-77]. We calculated ice melt below debris $M$ on an hourly basis (Equation 2), the negative yearly sum of which is equal to yearly SMB $b$ if there is no net mass gain, by simultaneously solving the heat equation (Equation 3) and the debris-surface energy balance (Equation 4):

$$
\begin{gathered}
M=\left.\frac{\Delta t}{\rho_{w} L_{f}} k_{d} \frac{\partial T_{s d}}{\partial z}\right|_{i} \\
\rho_{d} c_{d} \frac{\partial T_{s d}}{\partial t}=\frac{\partial}{\partial z}\left(k_{d} \frac{\partial T_{s d}}{\partial z}\right) \\
S+L+H+L E+P-\left.k_{d} \frac{\partial T_{s d}}{\partial z}\right|_{s}=0
\end{gathered}
$$

where $\Delta t$ is the time step of the model, $\rho_{w}$ is the density of water, $L_{f}$ is the latent heat of fusion of water, $k_{d}$ is the bulk thermal conductivity of debris, $T_{s d}$ is supraglacial debris temperature, $z$ is depth, $\rho_{d}$ is debris density, $c_{d}$ is the specific heat capacity of debris, $t$ is time, $S$ is the shortwave radiation flux at the debris surface, $L$ is the longwave radiation flux, $H$ is the sensible heat flux, $L E$ is the latent heat flux, $P$ is the heat flux due to precipitation, and the subscripts ${ }_{s}$ and $i$ indicate evaluation at the debris surface (the interface between the debris and the atmosphere above) and the ice surface (the interface between the debris and the ice below) respectively. We solved these equations by iteratively varying $T_{s d, s}$ using Newton's method and calculating debris internal temperatures using the Crank-Nicolson method, assuming $T_{s d, i}$ is the melting temperature of ice. If there was snow on the debris surface we set $T_{s d, s}$ to the melting temperature of ice, which shortly resulted in negligible ice melt below the debris if the snow persisted. We calculated the shortwave radiation flux broadly following [78]:

$$
S=\left(1-\alpha_{d}\right)\left(S \downarrow_{\text {dir }}+S \downarrow_{\text {dif }}\right)
$$



as:

where $S \downarrow_{\text {dif }}$ is the diffuse incoming shortwave radiation of the grid cell of the chosen point on the glacier surface, $\alpha_{d}$ is debris albedo and $S \downarrow_{d i r}$ is direct incoming shortwave radiation at the grid cell, which we calculated as:

$$
S \downarrow_{d i r}= \begin{cases}S \downarrow_{b, \text { dir }}\left[\sin Z \cos Z^{\prime}+\cos Z \sin Z^{\prime} \cos \left(A-A^{\prime}\right)\right], & \text { if the grid cell was in the sun } \\ 0, & \text { if the grid cell was in the shade }\end{cases}
$$

where $Z$ is solar zenith angle, $A$ is solar azimuth angle, $Z^{\prime}$ is the surface slope of the grid cell and $A^{\prime}$ is the surface azimuth of the grid cell. $S_{\downarrow_{b, d i r}}$ is direct incoming shortwave radiation normal to the solar beam, which we calculated as:

$$
S \downarrow_{b, d i r}=\frac{S \downarrow_{r, d i r}}{\sin Z}
$$

where $S \downarrow_{r, d i r}$ is the direct part of the incoming shortwave radiation of the nearest grid cell of the forcing dataset $S \downarrow_{r}:$

$$
S \downarrow_{r, d i r}=S \downarrow_{r}-S \downarrow_{r, d i f}
$$

where we calculated the diffuse part $S \downarrow_{\text {r,dif }}$ as:

$$
S \downarrow_{r, d i f}=f_{d i f} S \downarrow_{r}
$$

and where we set $f_{d i f}$, the fraction of incoming shortwave radiation that is diffuse, to 0.15 following [79]. We calculated diffuse incoming shortwave radiation at the grid cell as:

$$
S \downarrow_{\text {dif }}=f_{s v} S \downarrow_{r, \text { dif }}+S \downarrow_{t e r}
$$

where $f_{s v}$ is the sky-view factor of the grid cell and $S \downarrow_{t e r}$ is the shortwave radiation reflected to the grid cell from the surrounding terrain, which we calculated as:

$$
S \downarrow_{t e r}=\alpha_{t e r}\left(1-f_{s v}\right) S \downarrow_{r}
$$

where we assumed the albedo of the surrounding terrain $\alpha_{\text {ter }}$ to be 0.25 and

$$
f_{s v}=\sum_{\phi=0}^{360} \cos ^{2} \theta \frac{\Delta \phi}{360}
$$

where $\theta$ is the horizon angle at azimuth $\phi$ and $\Delta \phi$ is the azimuth step at which horizon angles are calculated, which we set to $12^{\circ}$. We determined whether the grid cell was in the shade or in the sun using the algorithm of [80], and calculated solar azimuth angle and solar elevation angle $E$ following [81], then calculated solar zenith angle as $Z=90-E$. We calculated the longwave radiation flux $L$, also following [78], as:

$$
L=L \downarrow_{s k y}+L \downarrow_{t e r}-L \uparrow
$$

where $L \downarrow_{s k y}$ is incoming longwave radiation from the sky that is visible at the grid cell, $L \downarrow_{\text {ter }}$ is longwave radiation emitted from nearby terrain, and $L \uparrow$ is outgoing longwave radiation from the debris surface. We calculated $L \downarrow_{s k y}$

$$
L \downarrow_{s k y}=L \downarrow_{r} f_{s v}
$$

where $L \downarrow_{r}$ is the incoming longwave radiation of the nearest forcing-dataset grid cell. We calculated $L \downarrow_{t e r}$ as

$$
L \downarrow_{t e r}=\left(1-f_{s v}\right) \sigma \varepsilon_{t e r} T_{t e r}^{4}
$$


where $\sigma$ is the Stefan-Boltzmann constant, $\varepsilon_{t e r}$ is the emissivity of the surrounding terrain, and $T_{t e r}$ is the temperature of the surrounding terrain, which we set to the air temperature of the grid cell $T_{a}$, which we lapsed from the nearest forcing-dataset grid cell according to $T_{a}=T_{a, r}-\Gamma\left(z-z_{r}\right)$, where $T_{a, r}$ is the temperature of the forcingdataset grid cell, $z_{r}$ is the elevation of the forcing-dataset grid cell, $z$ is the elevation of the grid cell, and $\Gamma$ is the lapse rate. We calculated $L \uparrow$ according to:

$$
L \uparrow=\sigma \varepsilon_{s d} T_{s d, s}^{4} .
$$

where $\varepsilon_{s d}$ is the emissivity of the debris. We calculated the sensible and latent heat fluxes following e.g. [82]:

$$
H=\rho_{a} c_{a, d r y} u\left(T_{a}-T_{s d, s}\right) C_{b t}
$$

$$
L E=\rho_{a} L_{v} u\left(q_{a}-q_{s}\right) C_{b t}
$$

where $\rho_{a}$ is the density of air, $c_{a, d r y}$ is the specific heat capacity of dry air, $u$ is the wind speed of the grid cell, corrected to the air-temperature reference height $\left(z_{r e f}, 2 \mathrm{~m}\right)$ from the wind speed $u_{r}$ of the nearest forcing-dataset grid cell using the logarithmic wind-profile law, and $L_{v}$ is the latent heat of vaporisation of water. $C_{b t}$ is a bulk transfer coefficient, which we calculated assuming neutral atmospheric stability from the reference height and the surface roughness length of the debris $z_{0, d}$ :

$$
C_{b t}=\frac{k_{v k}^{2}}{\left[\ln \left(z_{r e f} / z_{0, d}\right)\right]^{2}}
$$

where $k_{v k}$ is the von Kármán constant. We calculated $r h o_{a}$ as:

$$
\rho_{a}=\frac{p_{a} m_{a}}{R T_{a}}
$$

where $p_{a}$ is atmospheric pressure, which we calculated using the barometric formula, $m_{a}$ is the molecular weight of dry air, and $R$ is the gas constant. We calculated the specific humidity at the debris surface $q_{s}$, assuming that water vapour in the atmospheric surface layer is well-mixed [83], as

$$
q_{s}=q_{a} \frac{T_{s d, s}}{T_{a}}
$$

where $q_{a}$ is the specific humidity of the atmosphere above the debris surface, and $c_{a, d r y}$ is the specific heat capacity of dry air:

$$
c_{a, d r y}=c_{a}\left(1+0.84 q_{a}\right)
$$

We calculated the specific humidity of the atmosphere above the debris:

$$
q_{a}=\frac{0.622 e_{a}}{p_{a}-\left(0.378 e_{a}\right)}
$$

where $e_{a}$ is the vapour pressure of the atmosphere above the debris, which we calculated as:

$$
e_{a}=\frac{R H e_{a, s a t}}{100}
$$

from the saturated vapour pressure of the atmosphere above the debris surface [84]:

$$
e_{a, s a t}=610.78 \exp \left[\frac{17.27\left(T_{a}-273.15\right)}{T_{a}-35.86}\right]
$$


and the relative humidity $R H$ of the grid cell, which we calculated from forcing-dataset air and dew-point temperatures using the Clausius-Clapeyron equation. Finally we calculated the heat flux due to precipitation following [85] as:

$$
P=\rho_{w} c_{w} r\left(T_{r}-T_{s d, s}\right)
$$

where $c_{w}$ is the specific heat capacity of water, $r$ is the precipitation rate, and $T_{r}$ is the temperature of the precipitation, which we set to the air temperature of the grid cell.

The forcing dataset we developed comprises mean years, or mean yearly cycles, of the meteorological variables needed to force the energy-balance model, for the period of the 'measured' SMB data of [43]. For all variables except snow cover, we developed these mean years from the ERA5-Land reanalysis product [86], for the period 2000-2016, at hourly temporal and $0.1^{\circ}$ spatial resolution. An example is shown for air temperature for a location on Langtang Glacier, Nepal, in Supplementary Figure 22. For snow cover however, we used the dataset of [87], for the period 2002-2016, because of its higher 500-m spatial resolution, at the cost of its only 8-day temporal resolution. We used these mean years rather than complete time series for computational efficiency over such a large study area. We adjusted the precipitation mean year to avoid constant drizzle by allocating the mean yearly precipitation of the complete time series proportionally to the hours of the year in which, on average, most precipitation fell, such that the mean yearly number of precipitation hours of the complete time series was maintained. Likewise we adjusted the snow cover mean year to avoid constant snow cover by allocating snow cover to the periods of the year in which there was, on average, most snow cover, such that mean yearly snow cover duration was maintained. We used the ERA5-Land product to develop the forcing dataset because its high spatial resolution, and therefore explicit accommodation of glacierised elevations, along with its accommodation of cryospheric surface types, means it should resolve well glacier-surface-boundary-layer conditions, and be suitable for use directly in glacier energy-balance models with minimal additional downscaling [88, 89].

We calculated supraglacial debris volumes $V_{s d}$ as the product of SDT and debris-covered glacier area $A_{s d}$, where we computed $A_{s d}$ from the the debris-cover masks of [43], which were modified from [24].

We did not analyse all glaciers in HMA because i) the SMB data of [43] are limited to 5527 glaciers larger than $2 \mathrm{~km}^{2}$ and ii) we had to discard some, which exhibited erratic or unusual SDT profiles, which we took to be indicative of surging or poor-quality input data.

\section{Assessing uncertainty in supraglacial debris thickness and volume}

We assessed SDT uncertainty at the point scale by combining uncertainties in modelled and measured SMB using the fitted Østrem curves (Supplementary Figure 21). Uncertainty in modelled SMB for debris-free glaciers is dominated by uncertainty in i) air temperature forcing, ii) surface albedo and iii) air temperature lapse rate [90]. For debris-covered glaciers, additionally important is uncertainty in: iv) debris thermal conductivity and v) debris surface roughness length $[28,91]$. Therefore, for modelled SMB in this study, we accounted for uncertainty in these five variables and parameters. We did this through the Monte Carlo simulations described above. We did not consider uncertainty in precipitation because we dealt with snow cover using observations, and the energy flux due to precipitation is typically relatively small [85]. Based on the finding of [90] that uncertainty in modelled SMB is dominated by systematic rather than random error, we assigned systematic errors to these variables and parameters in the Monte Carlo simulations, i.e. for each simulation we did not vary the assigned errors in time. 
The distributions from which we drew errors and variable or parameter values are given in Supplementary Table 4. We took uncertainty in measured SMB directly from [43], and assumed this too to be systematic at the point scale. Because the fitted Østrem curves are nonlinear, SDT uncertainty is asymmetric.

We assessed uncertainty in mean SDT at the regional (subregional) scale by assuming no uncertainty in measured SMB and by running the Monte Carlo simulations again but without assigning errors to the air temperature forcing, then taking the means of the region's (subregion's) point-scale SDT uncertainties, both positive and negative. We did this on the basis that air temperature forcing and measured SMB errors are likely to be random and therefore negligible, rather than systematic, at such large spatial scales.

We assessed debris volume uncertainty $\sigma_{V_{s d}}$ at the regional (subregional) scale according to:

$$
\sigma_{V_{s d}}=\left|V_{s d}\right| \sqrt{\left(\frac{\sigma_{A_{s d}}}{A_{s d}}\right)^{2}+\left(\frac{\sigma_{h_{s d}^{-}}}{h_{s d}^{-}}\right)^{2}}
$$

where $\overline{h_{s d}}$ is regional (subregional) mean SDT with uncertainty $\sigma_{h_{s d}^{-}}$, and where $A_{s d}$ is the debris-covered area of the study glaciers in that region (subregion) with an estimated relative uncertainty, for the dataset of [24], of 10\% [1].

\section{Calculating debris-supply rate and englacial debris content}

We calculated DSR, $q_{d s}$, as a mean value for each glacier's debris-supply slopes by assuming conservation of mass of debris to the glacier's surface, from its debris-supply slopes, via its interior (Supplementary Figure 23a), such that:

$$
\rho_{r} q_{d s} A_{d s}=\rho_{d} q_{e d} A_{s d}
$$

where $\rho_{d}$ is debris density, $A_{d s}$ is debris-supply-slope area calculated as described below then converted from planimetric to terrain-perpendicular, $\rho_{r}$ is rock density, $q_{e d}$ is the rate of emergence of englacial debris at the glacier surface, and $A_{s d}$ is the area of the glacier that is debris covered [37, 90]. We used values of $1842 \mathrm{~kg} \mathrm{~m}^{-3}$ and $2700 \mathrm{~kg} \mathrm{~m}^{-3}$ for debris and rock density respectively. The units of all variables are provided in Supplementary Table 5.

In order to account for debris losses on the lower, inactive parts of glaciers due to surface-hydrology transport and export to moraines (Supplementary Figure 23b), and in order that calculated debris-supply rates represent recent debris supply [92] (Supplementary Figure 23a), we calculated the volume flux of englacial debris to each glacier's surface $q_{e d} A_{s d}$ by splitting each glacier's debris-covered part into two: an active part and an inactive part (Supplementary Figure 23b):

$$
q_{e d} A_{s d}=q_{e d, a} A_{s d, a}+q_{e d, i a} A_{s d, i a}
$$

where $q_{e d, a}$ and $q_{e d, i a}$ are the emergence rates of englacial debris to the surfaces of the active and inactive parts respectively, where $A_{s d, a}$ and $A_{s d, i a}$ are the areas of the active and inactive parts respectively, and where:

$$
q_{e d, a}=\frac{Q_{s d, a \uparrow}-Q_{s d, a \downarrow}}{A_{s d, a}}=\nabla \cdot \overrightarrow{Q_{s d, a}}
$$

(Supplementary Figure 23c). Here, $Q_{s d, a \downarrow}$ and $Q_{s d, a \uparrow}$ are the volume fluxes of surface debris into and out of the active part respectively where $Q_{s d, a \downarrow}$ is zero, and $\nabla Q_{s d, a}$ is the divergence of the volume flux of the surface debris 
in the active part, where we calculated the volume fluxes of the surface debris at flux gates:

$$
Q_{s d}=\int_{\Omega} h_{s d} u_{s d} d y
$$

where $u_{s d}$ is the the down-glacier component of the surface-velocity field of the debris at the flux gate (taken from the velocity fields of [43]), $\Omega$ is the glacier boundary, and $y$ is the across-glacier direction. We considered the active part of the glacier to be that which is up-glacier of the gate of maximum volume flux of surface debris, and, in order to avoid very high flux divergences, we applied a moving-mean filter to the volume fluxes of surface debris, such that each smoothed volume flux data point comprised $10 \%$ of all the volume flux data points.

From $q_{e d, a}$, we calculated englacial debris content in the ablation area of the glacier $c_{e d, a b l}$ such that:

$$
c_{e d, a b l}=\frac{q_{e d, a} \rho_{d}}{M_{a} \rho_{r}+q_{e d, a} \rho_{d}}
$$

where $M_{a}$ is the melt rate of the active part of the debris-covered part of each glacier, converted to ice equivalent from the SMB data of [43] using a density of $915 \mathrm{~kg} \mathrm{~m}^{-3}$, leaving the emergence rate of englacial debris to the surface of the inactive part $q_{e d, i a}$ to be calculated as:

$$
q_{e d, i a}=\frac{c_{e d, a b l} M_{i a} \rho_{r}}{\rho_{d}-c_{e d, a b l} \rho_{d}}
$$

where $M_{i a}$ is the melt rate of the inactive part.

To calculate the englacial debris content of the whole of each glacier, we performed a density conversion using a bulk glacier density of $850 \mathrm{~kg} \mathrm{~m}^{-3}$ [93]:

$$
c_{e d, g l a c}=c_{e d, a b l} \frac{\rho_{i, a b l}}{\rho_{i, g l a c}}
$$

We delineated each glacier's debris-supply slopes, the areas above the glacier that are able to contribute debris to it through erosion, by i) identifying the upslope areas of the glacier's debris-covered parts and ii) identifying and subtracting from these upslope areas overlapping glacierised areas, where there is no erodable rock surface. Example debris-supply slopes can be seen in Figure 2. We identified each glacier's upslope areas by i) filling sinks in an elevation model of the area surrounding the glacier, ii) placing pour points at the at the 75 th percentile elevation of the glacier's debris elevation range, or anywhere there was a debris-ice transition below the 75 th percentile elevation, iii) downsampling these pour points so that there was a maximum of one every $100 \mathrm{~m}$, iv) refining the locations of the downsampled pour points by searching locally for those with the highest topographic index, v) calculating the upslope areas of the refined pour points, vi) merging these upslope areas. We identified the glacierised areas by modifying Randolph Glacier Inventory (RGI) v6.0 glacier areas [48], which sometimes incorrectly identify snow as glacier area, by i) deriving Normalised-Difference Snow Index (NDSI) for each glacier for the duration of the [43] SMB data from Landsat 5-8 imagery in Google Earth Engine, ii) thresholding the NDSI images to identify rock outcrops within the RGI glacier areas using Otsu's method, and iii) subtracting these rock outcrops from the RGI glacier areas.

To calculate mean DSR and englacial debris content at the regional (subregional) scale, we normalised glacierscale means by calculated debris-supply-slope area and and glacier volume [94], respectively.

We were only able to calculate DSR and englacial debris content for 4094 of the 4863 glaciers for which we calculated SDT because some glaciers did not carry any debris and so could not produce a meaningful calculation of the rate of emergence of englacial debris to their surfaces. 
We note that we calculate DSR rather than headwall-erosion rate because some of the debris that is eroded from a glacier's headwall or debris-supply slopes may go straight to the bed of the glacier and never reach its surface, and Equation 28 does not account for debris that is lost in this way.

\section{Assessing uncertainty in debris-supply rate and englacial debris content}

We assessed the uncertainty in each glacier's DSR as the sum in quadrature of the uncertainties in Equation 28's constituent variables and parameters:

$$
\sigma_{q_{d s}}=\left|q_{d s}\right| \sqrt{\left(\frac{\sigma_{\rho_{d}}}{\rho_{d}}\right)^{2}+\left(\frac{\sigma_{q_{e d} A_{s d}}}{q_{e d} A_{s d}}\right)^{2}+\left(\frac{\sigma_{\rho_{r}}}{\rho_{r}}\right)^{2}+\left(\frac{\sigma_{A_{d s}}}{A_{d s}}\right)^{2}}
$$

where we estimated $\sigma_{\rho_{d}}$ and $\sigma_{\rho_{r}}$, the uncertainties in debris and rock density respectively, to be $100 \mathrm{~kg} \mathrm{~m}^{-2}$, and where we estimated the relative uncertainty in $A_{d s}$ to be $10 \%$. We calculated $\sigma_{q_{e d} A_{s d}}$ by propagating uncertainties through Equation 29, as:

$$
\sigma_{q_{e d} A_{s d}}=\sqrt{\left(q_{e d, a} \sigma_{A_{s d, a}}\right)^{2}+\left(A_{s d, a} \sigma_{q_{e d, a}}\right)^{2}+\left(q_{e d, i a} \sigma_{A_{s d, i a}}\right)^{2}+\left(A_{s d, i a} \sigma_{q_{e d, i a}}\right)^{2}}
$$

where we estimated the relative uncertainties of $A_{s d, a}$ and $A_{s d, i a}$ to be $10 \%$, where:

$$
\sigma_{q_{e d, a}}=\left|q_{e d, a}\right| \sqrt{\left(\frac{\sigma_{Q_{s d, a \uparrow}}}{Q_{s d, a \uparrow}}\right)^{2}+\left(\frac{\sigma_{A_{s d, a}}}{A_{s d, a}}\right)^{2}}
$$

where we assumed $\sigma_{Q_{s d, a \uparrow}}$ is dominated by $\sigma_{h_{s d}}$, and, for simplicity, where:

$$
\frac{\sigma_{q_{e d, i a}}}{q_{e d, i a}} \approx \frac{\sigma_{q_{e d, a}}}{q_{e d, a}}
$$

We assessed ablation zone englacial debris content uncertainty, also at the glacier scale, according to Equation 32 as:

$$
\sigma_{c_{e d, a b l}}=\left|c_{e d, a b l}\right| \sqrt{\left(\frac{\sigma_{q_{e d, a}}}{q_{e d, a}}\right)^{2}+\left(\frac{\sigma_{\rho_{d}}}{\rho_{d}}\right)^{2}+\left(\frac{\sigma_{M_{a}}}{M_{a}}\right)^{2}+\left(\frac{\sigma_{\rho_{r}}}{\rho_{r}}\right)^{2}-2 \frac{\sigma_{M_{a} q_{e d, a}}}{M_{a} q_{e d, a}}}
$$

where we took $\sigma_{M_{a}}$ from the SMB uncertainties of [43], and where $\sigma_{M_{a} q_{e d, a}}$ is the covariance of $\sigma_{M_{a}}$ and $\sigma_{q_{e d, a}}$, which we calculated using the Cauchy-Schwarz inequality, and which arises because the SDT uncertainties include the SMB uncertainties of [43]. To get whole-glacier englacial debris content uncertainty, we propagated the uncertainties of Equation 34:

$$
\sigma_{c_{e d, g l a c}}=\left|c_{e d, g l a c}\right| \sqrt{\left(\frac{\sigma_{c_{e d, a b l}}}{c_{e d, a b l}}\right)^{2}+\left(\frac{\sigma_{\rho_{i, a b l}}}{\rho_{i, a b l}}\right)^{2}+\left(\frac{\sigma_{\rho_{i, g l a c}}}{\rho_{i, g l a c}}\right)^{2}}
$$

where $\sigma_{\rho_{i, g l a c}}$ and $\rho_{i, g l a c}$ were assumed to be 60 and $850 \mathrm{~kg} \mathrm{~m}^{-3}$ following [93], and the relative uncertainty of the density of ablation-zone ice was assumed to be negligible.

Because SDT uncertainty is asymmetric, so is uncertainty in the rate of debris emergence at the glacier surface, and therefore DSR and englacial debris content. As such, we assessed positive and negative DSR and englacial debris content uncertainties separately.

We assessed uncertainty in mean DSR and englacial debris content at the regional (subregional) scale in a similar way as for SDT, as described above. We produced a second set of glacier-scale DSR and englacial debris content uncertainties, using the SDT uncertainties of the second set of Monte Carlo simulations (also described 


\section{${ }_{384}$ Code availability}

\section{Data availability}

\section{Acknowledgements} glaciers in High Mountain Asia”.

\section{Author contributions} results and write the paper.

\section{Competing interests}

above-those that are exclusive of uncertainty in air temperature and measured SMB) and assuming no uncertainty in $M_{a}$ in Equation 39, and took the means of the upper and lower bounds of these uncertainties, normalising by debris-supply-slope area and glacier volume, for DSR and englacial debris content, respectively. In this way, uncertainties in mean DSR and englacial debris content at the regional (subregional) scale, as do uncertainties in SDT, account for the likely random nature of the uncertainty in air-temperature forcing and measured SMB at such large scales, and the likely systematic nature of the uncertainty in other key input variables and parameters.

The supraglacial debris thicknesss, englacial debris content and debris-supply rate data that support the findings of this study will be made available on publication of this study in a Zenodo repository.

The code used to generate the supraglacial debris thickness, englacial debris content and debris-supply rate data of this study will be made available on publication of this study in a GitHub repository.

We thank Bhanu Pratap and Lavkush Patel for providing in-situ supraglacial debris thickness data for validation. This project has received funding from the European Research Council (ERC) under the European Union's Horizon 2020 research and innovation program grant agreement No 772751, RAVEN, "Rapid mass losses of debris-covered

MM, EM and FP designed the study and developed the methods for calculating supraglacial debris thickness and debris-supply rate. MK, PB and EM mapped and developed the methods for mapping the debris-supply slopes. MM performed the calculations and led the writing of the paper. EM, FP, SF, MK and PB helped interpret the

The authors declare no competing interests. 


\section{References}

1. Herreid, S. \& Pellicciotti, F. The state of rock debris covering Earth's glaciers. Nature Geoscience 13, 621$627(2020)$

2. Kirkbride, M. P. \& Warren, C. R. Tasman Glacier, New Zealand: 20th-century thinning and predicted calving retreat. Global and Planetary Change 22, 11-28 (1999).

3. Deline, P. \& Orombelli, G. Glacier fluctuations in the western Alps during the Neoglacial, as indicated by the Miage morainic amphitheatre (Mont Blanc massif, Italy). Boreas 34, 456-467 (2005).

4. Kellerer-Pirklbauer, A. The supraglacial debris system at the Pasterze Glacier, Austria: spatial distribution, characteristics and transport of debris. Zeitschrift für Geomorphologie, Supplementary Issues, 3-25 (2008).

5. Thakuri, S. et al. Tracing glacier changes since the 1960s on the south slope of Mt. Everest (central Southern Himalaya) using optical satellite imagery. The Cryosphere 8, 1297-1315 (2014).

6. Xie, F. et al. Upward Expansion of Supra-Glacial Debris Cover in the Hunza Valley, Karakoram, During 1990 2019. Frontiers in Earth Science 8, 308 (2020).

7. Jiang, S. et al. Glacier change, supraglacial debris expansion and glacial lake evolution in the Gyirong river basin, central Himalayas, between 1988 and 2015. Remote Sensing 10, 986 (2018).

8. Glasser, N. F. et al. Recent spatial and temporal variations in debris cover on Patagonian glaciers. Geomorphology 273, 202-216 (2016).

9. Tielidze, L. G. et al. Supra-glacial debris cover changes in the Greater Caucasus from 1986 to 2014. The Cryosphere 14, 585-598 (2020).

10. Ostrem, G. Ice melting under a thin layer of moraine, and the existence of ice cores in moraine ridges. Geografiska Annaler 41, 228-230 (1959).

11. Mattson, L. Ablation on debris covered glaciers: an example from the Rakhiot Glacier, Punjab, Himalaya. Intern. Assoc. Hydrol. Sci. 218, 289-296 (1993).

12. Scherler, D., Bookhagen, B. \& Strecker, M. R. Spatially variable response of Himalayan glaciers to climate change affected by debris cover. Nature Geoscience 4, 156-159 (2011).

13. Ragettli, S., Immerzeel, W. W. \& Pellicciotti, F. Contrasting climate change impact on river flows from high-altitude catchments in the Himalayan and Andes Mountains. Proceedings of the National Academy of Sciences 113, 9222-9227 (2016).

14. Anderson, L. S. \& Anderson, R. S. Modeling debris-covered glaciers: response to steady debris deposition. The Cryosphere 10, 1105-1124 (2016).

15. Quincey, D., Luckman, A. \& Benn, D. Quantification of Everest region glacier velocities between 1992 and 2002, using satellite radar interferometry and feature tracking. Journal of Glaciology 55, 596-606 (2009).

16. Benn, D. et al. Response of debris-covered glaciers in the Mount Everest region to recent warming, and implications for outburst flood hazards. Earth-Science Reviews 114, 156-174 (2012).

17. Fyffe, C. et al. Do debris-covered glaciers demonstrate distinctive hydrological behaviour compared to clean glaciers? Journal of Hydrology 570, 584-597 (2019). 
18. Miles, K. E. et al. Hydrology of debris-covered glaciers in High Mountain Asia. Earth-Science Reviews 207, 103212 (2020).

19. Immerzeel, W. W., Van Beek, L. P. \& Bierkens, M. F. Climate change will affect the Asian water towers. Science 328, 1382-1385 (2010).

20. Pritchard, H. D. Asia's shrinking glaciers protect large populations from drought stress. Nature 569, 649-654 (2019).

21. Immerzeel, W. W. et al. Importance and vulnerability of the worlds water towers. Nature 577, 364-369 (2020).

22. Cauvy-Fraunié, S. \& Dangles, O. A global synthesis of biodiversity responses to glacier retreat. Nature Ecology \& Evolution 3, 1675-1685 (2019).

23. Kraaijenbrink, P. D., Bierkens, M., Lutz, A. \& Immerzeel, W. Impact of a global temperature rise of 1.5 degrees Celsius on Asias glaciers. Nature 549, 257-260 (2017).

24. Scherler, D., Wulf, H. \& Gorelick, N. Global assessment of supraglacial debris-cover extents. Geophysical Research Letters 45, 11-798 (2018).

25. Rounce, D. R., Hock, R. \& Shean, D. E. Glacier mass change in High Mountain Asia through 2100 using the open-source Python glacier evolution model (PyGEM). Frontiers in Earth Science 7, 331 (2020).

26. Schauwecker, S. et al. Remotely sensed debris thickness mapping of Bara Shigri glacier, Indian Himalaya. Journal of Glaciology 61, 675-688 (2015).

27. Rounce, D. \& McKinney, D. Debris thickness of glaciers in the Everest area (Nepal Himalaya) derived from satellite imagery using a nonlinear energy balance model. The Cryosphere 8, 1317-1329 (2014).

28. Rounce, D. R., King, O., McCarthy, M., Shean, D. E. \& Salerno, F. Quantifying debris thickness of debriscovered glaciers in the Everest Region of Nepal through inversion of a subdebris melt model. Journal of Geophysical Research: Earth Surface 123, 1094-1115 (2018).

29. Huang, L. et al. Estimation of supraglacial debris thickness using a novel target decomposition on L-band polarimetric SAR images in the Tianshan Mountains. Journal of Geophysical Research: Earth Surface 122, 925-940 (2017).

30. McCarthy, M. J. Quantifying supraglacial debris thickness at local to regional scales $\mathrm{PhD}$ thesis (University of Cambridge, 2018).

31. Rounce, D. et al. Distributed global debris thickness estimates reveal debris significantly impacts glacier mass balance. Geophysical Research Letters (2021).

32. Boxall, K., Willis, I., Giese, A. \& Liu, Q. Quantifying Patterns of Supraglacial Debris Thickness and Their Glaciological Controls in High Mountain Asia. Frontiers in Earth Science 9, 504 (2021).

33. Herreid, S. What can thermal imagery tell us about glacier melt below rock debris? Frontiers in Earth Science 9, 1-19 (2021). 
34. Scherler, D. \& Egholm, D. Production and transport of supraglacial debris: Insights from cosmogenic 10Be and numerical modeling, Chhota Shigri Glacier, Indian Himalaya. Journal of Geophysical Research: Earth Surface 125, e2020JF005586 (2020).

35. Orr, E. N., Owen, L. A., Saha, S., Hammer, S. J. \& Caffee, M. W. Rockwall slope erosion in the northwestern Himalaya. Journal of Geophysical Research: Earth Surface 126, e2020JF005619 (2020).

36. Heimsath, A. M. \& McGlynn, R. Quantifying periglacial erosion in the Nepal high Himalaya. Geomorphol$\operatorname{ogy} 97,5-23$ (2008).

37. Banerjee, A. \& Wani, B. A. Exponentially decreasing erosion rates protect the high-elevation crests of the Himalaya. Earth and Planetary Science Letters 497, 22-28 (2018).

38. Barker, A. Glaciers, erosion and climate change in the Himalaya and St. Elias Range, SE Alaska PhD thesis (2016).

39. Shah, S. S., Banerjee, A., Nainwal, H. C. \& Shankar, R. Estimation of the total sub-debris ablation from point-scale ablation data on a debris-covered glacier. Journal of Glaciology 65, 759-769 (2019).

40. Miles, K. E. et al. Continuous borehole optical televiewing reveals variable englacial debris concentrations at Khumbu Glacier, Nepal. Communications Earth \& Environment 2, 1-9 (2021).

41. Nakawo, M. Supraglacial debris of G2 glacier in Hidden Valley, Mukut Himal, Nepal. Journal of Glaciology 22, 273-283 (1979).

42. Shroder Jr, J. F. in Himalaya to the Sea 134-141 (Routledge, 2002).

43. Miles, E. et al. Health and sustainability of glaciers in High Mountain Asia. Nature Communications 12, 2868 (2021).

44. Anderson, L. S. \& Anderson, R. S. Debris thickness patterns on debris-covered glaciers. Geomorphology 311, 1-12 (2018).

45. Kirkbride, M. P. \& Deline, P. The formation of supraglacial debris covers by primary dispersal from transverse englacial debris bands. Earth Surface Processes and Landforms 38, 1779-1792 (2013).

46. Anderson, R. S. A model of ablation-dominated medial moraines and the generation of debris-mantled glacier snouts. Journal of Glaciology 46, 459-469 (2000).

47. Hock, R. et al. High Mountain Areas: In: IPCC Special Report on the Ocean and Cryosphere in a Changing Climate tech. rep. (IPCC, 2019).

48. RGI-Consortium. Randolph Glacier Inventory - A Dataset of Global Glacier Outlines: Version 6.0: Technical Report tech. rep. (Global Land Ice Measurements from Space, Colorado, USA, 2017).

49. Dehecq, A. et al. Twenty-first century glacier slowdown driven by mass loss in High Mountain Asia. Nature Geoscience 12, 22-27 (2019).

50. Cook, S. J., Swift, D. A., Kirkbride, M. P., Knight, P. G. \& Waller, R. I. The empirical basis for modelling glacial erosion rates. Nature Communications 11, 1-7 (2020).

51. Kirchner, J. W. et al. Mountain erosion over $10 \mathrm{yr}, 10 \mathrm{ky}$, and 10 my time scales. Geology 29, 591-594 (2001). 
52. Chen, J. \& Ohmura, A. Estimation of Alpine glacier water resources and their change since the 1870 s. IAHS Publication 193, 127-135 (1990).

53. Fick, S. E. \& Hijmans, R. J. WorldClim 2: new 1-km spatial resolution climate surfaces for global land areas. International Journal of Climatology 37, 4302-4315 (2017).

54. Hales, T. \& Roering, J. J. Climatic controls on frost cracking and implications for the evolution of bedrock landscapes. Journal of Geophysical Research: Earth Surface 112 (2007).

55. Scherler, D. Climatic limits to headwall retreat in the Khumbu Himalaya, eastern Nepal. Geology 42, 10191022 (2014).

56. Eppes, M.-C. \& Keanini, R. Mechanical weathering and rock erosion by climate-dependent subcritical cracking. Reviews of Geophysics 55, 470-508 (2017).

57. Hirschberg, J. et al. Climate Change Impacts on Sediment Yield and Debris-Flow Activity in an Alpine Catchment. Journal of Geophysical Research: Earth Surface (2020).

58. Montgomery, D. R. \& Brandon, M. T. Topographic controls on erosion rates in tectonically active mountain ranges. Earth and Planetary Science Letters 201, 481-489 (2002).

59. Larsen, I. J. \& Montgomery, D. R. Landslide erosion coupled to tectonics and river incision. Nature Geoscience 5, 468-473 (2012).

60. Nagai, H., Fujita, K., Nuimura, T. \& Sakai, A. Southwest-facing slopes control the formation of debriscovered glaciers in the Bhutan Himalaya. The Cryosphere 7, 1303-1314 (2013).

61. Collins, B. D. \& Stock, G. M. Rockfall triggering by cyclic thermal stressing of exfoliation fractures. Nature Geoscience 9, 395-400 (2016).

62. Hartmann, J. \& Moosdorf, N. The new global lithological map database GLiM: A representation of rock properties at the Earth surface. Geochemistry, Geophysics, Geosystems 13 (2012).

63. Schmidt, K. M. \& Montgomery, D. R. Limits to relief. Science 270, 617-620 (1995).

64. Benn, D. I., Kirkbride, M. P., Owen, L. A. \& Brazier, V. Glaciated valley landsystems. Glacial landsystems, 372-406 (2003).

65. Brun, F. et al. Heterogeneous influence of glacier morphology on the mass balance variability in High Mountain Asia. Journal of Geophysical Research: Earth Surface 124, 1331-1345 (2019).

66. Rowan, A. V., Egholm, D. L., Quincey, D. J. \& Glasser, N. F. Modelling the feedbacks between mass balance, ice flow and debris transport to predict the response to climate change of debris-covered glaciers in the Himalaya. Earth and Planetary Science Letters 430, 427-438 (2015).

67. Zarfl, C., Lumsdon, A. E., Berlekamp, J., Tydecks, L. \& Tockner, K. A global boom in hydropower dam construction. Aquatic Sciences 77, 161-170 (2015).

68. Gibson, M. J. et al. Temporal variations in supraglacial debris distribution on Baltoro Glacier, Karakoram between 2001 and 2012. Geomorphology 295, 572-585 (2017).

69. Woerkom, T. v., Steiner, J. F., Kraaijenbrink, P. D., Miles, E. S. \& Immerzeel, W. W. Sediment supply from lateral moraines to a debris-covered glacier in the Himalaya. Earth Surface Dynamics 7, 411-427 (2019). 
70. Ragettli, S. et al. Unraveling the hydrology of a Himalayan catchment through integration of high resolution in situ data and remote sensing with an advanced simulation model. Advances in Water Resources 78, 94-111 (2015).

71. Westoby, M. J. et al. Geomorphological evolution of a debris-covered glacier surface. Earth Surface Processes and Landforms 45, 3431-3448 (2020).

72. Evatt, G. W. et al. Glacial melt under a porous debris layer. Journal of Glaciology 61, 825-836 (2015).

73. Buri, P., Miles, E. S., Steiner, J. F., Ragettli, S. \& Pellicciotti, F. Supraglacial Ice Cliffs Can Substantially Increase the Mass Loss of Debris-Covered Glaciers. Geophysical Research Letters 48, e2020GL092150 (2021).

74. Miles, E. S. et al. Surface pond energy absorption across four Himalayan glaciers accounts for 1/8 of total catchment ice loss. Geophysical Research Letters 45, 10-464 (2018).

75. Reid, T. D. \& Brock, B. W. An energy-balance model for debris-covered glaciers including heat conduction through the debris layer. Journal of Glaciology 56, 903-916 (2010).

76. Reid, T., Carenzo, M., Pellicciotti, F. \& Brock, B. Including debris cover effects in a distributed model of glacier ablation. Journal of Geophysical Research: Atmospheres 117 (2012).

77. Rounce, D., Quincey, D. \& McKinney, D. Debris-covered energy balance model for Imja-Lhotse Shar Glacier in the Everest region of Nepal. The Cryosphere 9, 3503-3540 (2015).

78. Arnold, N. S., Rees, W. G., Hodson, A. J. \& Kohler, J. Topographic controls on the surface energy balance of a high Arctic valley glacier. Journal of Geophysical Research: Earth Surface 111 (2006).

79. Konzelmann, T. \& Ohmura, A. Radiative fluxes and their impact on the energy balance of the Greenland ice sheet. Journal of Glaciology 41, 490-502 (1995).

80. Arnold, N., Willis, I., Sharp, M., Richards, K. \& Lawson, W. A distributed surface energy-balance model for a small valley glacier. I. Development and testing for Haut Glacier dArolla, Valais, Switzerland. Journal of Glaciology 42, 77-89 (1996).

81. Walraven, R. Calculating the position of the sun. Solar Energy 20, 393-397 (1978).

82. Paterson, W. S. B. Physics of glaciers (Butterworth-Heinemann, 1994).

83. Collier, E. et al. Representing moisture fluxes and phase changes in glacier debris cover using a reservoir approach. The Cryosphere 8, 1429-1444 (2014).

84. Murray, F. W. On the computation of saturation vapor pressure. Journal of Applied Meteorology and Climatology, 203-204 (1967).

85. Hay, J. \& Fitzharris, B. A comparison of the energy-balance and bulk-aerodynamic approaches for estimating glacier melt. Journal of Glaciology 34, 145-153 (1988).

86. ERA5-Land hourly data from 1981 to present. Copernicus Climate Change Service (C3S) Climate Data Store (CDS). Accessed on 01-01-2020 (2019).

87. Muhammad, S. \& Thapa, A. An improved Terra-Aqua MODIS snow cover and Randolph Glacier Inventory 6.0 combined product (MOYDGL06*) for high-mountain Asia between 2002 and 2018. Earth System Science Data 12, 345-356 (2020). 
88. Mölg, T. \& Kaser, G. A new approach to resolving climate-cryosphere relations: Downscaling climate dynamics to glacier-scale mass and energy balance without statistical scale linking. Journal of Geophysical Research: Atmospheres 116 (2011).

89. Mölg, T., Maussion, F. \& Scherer, D. Mid-latitude westerlies as a driver of glacier variability in monsoonal High Asia. Nature Climate Change 4, 68-73 (2014).

90. Machguth, H., Purves, R. S., Oerlemans, J., Hoelzle, M. \& Paul, F. Exploring uncertainty in glacier mass balance modelling with Monte Carlo simulation. The Cryosphere 2, 191-204 (2008).

91. Miles, E. S., Steiner, J. F. \& Brun, F. Highly variable aerodynamic roughness length (z0) for a hummocky debris-covered glacier. Journal of Geophysical Research: Atmospheres 122, 8447-8466 (2017).

92. Wirbel, A., Jarosch, A. H. \& Nicholson, L. Modelling debris transport within glaciers by advection in a full-Stokes ice flow model. The Cryosphere 12, 189-204 (2018).

93. Huss, M. Density assumptions for converting geodetic glacier volume change to mass change. The Cryosphere 7, 877-887 (2013).

94. Farinotti, D. et al. A consensus estimate for the ice thickness distribution of all glaciers on Earth. Nature Geoscience 12, 168-173 (2019). 


\title{
Supplementary information: Supraglacial debris thickness and supply rate in High-Mountain Asia
}

\author{
Michael McCarthy ${ }^{*}, 1,2$, Evan Miles ${ }^{1}$, Marin Kneib ${ }^{1,3}$, Pascal Buri ${ }^{1}$, Stefan Fugger ${ }^{1,3}$, \\ Francesca Pellicciotti ${ }^{1,4}$ \\ Correspondence to: michael.mccarthy@wsl.ch \\ 1. Swiss Federal Research Institute WSL, Birmensdorf, Switzerland \\ 2. British Antarctic Survey, Natural Environment Research Council, Cambridge, UK \\ 3. Institute of Environmental Engineering, ETH Zurich, Zurich, Switzerland \\ 4. Department of Geography, Northumbria University, Newcastle, UK
}

December 3, 2021 
Supplementary Table 1: Glaciers in High-Mountain Asia at which supraglacial debris thickness measurements have been made. * indicates unpublished data collected by the authors. RGIID is the identification number for the glacier in the Randolph Glacier Inventory (RGI) v6.0 [1]. Note that measurements have been made multiple times on some glaciers.

\begin{tabular}{|c|c|c|c|c|}
\hline Reference & Glacier & Latitude & Longitude & RGIID \\
\hline$[2]$ & Ngozumpa & 28.001 & 86.692 & RGI60-15.03473 \\
\hline [3] & Dokriani & 30.861 & 78.817 & RGI60-15.07605 \\
\hline$[4]$ & Rakhiot & 35.34 & 74.583 & RGI60-14.20156 \\
\hline$[5]$ & Lirung & 28.238 & 85.556 & RGI60-15.04045 \\
\hline [6] & Batal & 32.341 & 77.583 & RGI60-14.16042 \\
\hline [7] & Imja-Lhotse Shar & 27.896 & 86.938 & RGI60-15.03743 \\
\hline [8] & Baltoro & 35.736 & 76.162 & RGI60-14.06794 \\
\hline [9] & Ngozumpa & 28.001 & 86.692 & RGI60-15.03473 \\
\hline$*$ & Langtang & 28.288 & 85.72 & RGI60-15.04121 \\
\hline$*$ & Lirung & 28.238 & 85.556 & RGI60-15.04045 \\
\hline$[10]$ & Hamtah & 77.362 & 32.253 & RGI60-14.15536 \\
\hline [11] & Hailuogou & 29.558 & 101.965 & RGI60-15.07886 \\
\hline [12] & $24 \mathrm{~K}$ & 29.75 & 95.717 & RGI60-15.11758 \\
\hline$[13]$ & Satopanth & 30.73 & 79.32 & RGI60-15.07122 \\
\hline [14] & Koxkar & 41.758 & 80.118 & RGI60-13.43232 \\
\hline [15] & Chorabari & 30.767 & 79.067 & RGI60-15.06941 \\
\hline [16] & Pensilungpa & 33.823 & 76.287 & RGI60-14.18909 \\
\hline [17] & Shaigiri & 35.184 & 74.57 & RGI60-14.19394 \\
\hline [18] & Khumbu & 27.948 & 86.807 & RGI60-15.03733 \\
\hline [19] & Inylchek & 42.158 & 79.933 & RGI60-13.05000 \\
\hline$[20]$ & Milarepa & 28.633 & 84.042 & RGI60-15.04770 \\
\hline$[21]$ & Changri Nup & 27.994 & 86.781 & RGI60-15.03734 \\
\hline$[22]$ & Khumbu & 27.948 & 86.807 & RGI60-15.03733 \\
\hline$[23]$ & Baltoro & 35.736 & 76.162 & RGI60-14.06794 \\
\hline$[24]$ & Koxkar & 41.758 & 80.118 & RGI60-13.43232 \\
\hline$[25]$ & $\mathrm{G} 2$ & 28.785 & 83.561 & RGI60-15.04410 \\
\hline$[26]$ & 72 & 42 & 79.912 & RGI60-13.43165 \\
\hline$[26]$ & 74 & 41.751 & 79.95 & RGI60-13.43174 \\
\hline [26] & Tuomer & 41.921 & 80.006 & RGI60-13.43207 \\
\hline$[27]$ & Panchi Nala & 32.705 & 77.332 & RGI60-14.14910 \\
\hline [28] & Khumbu & 27.948 & 86.807 & RGI60-15.03733 \\
\hline
\end{tabular}


Supplementary Table 2: Glaciers in High-Mountain Asia above which headwall-erosion rate measurements have been made. RGIID is the identification number for the glacier in the Randolph Glacier Inventory (RGI) v6.0 [1].

\begin{tabular}{ccccc}
\hline Study & Glacier & Latitude & Longitude & RGIID \\
\hline$[29]$ & Khumbu & 27.948 & 86.807 & RGI60-15.03733 \\
{$[30]$} & Baltoro & 35.736 & 76.162 & RGI60-14.06794 \\
{$[20]$} & Milarepa & 28.633 & 84.042 & RGI60-15.04770 \\
{$[31]$} & Siachen & 35.331 & 77.229 & RGI60-14.07524 \\
{$[32]$} & Gangotri & 30.874 & 79.103 & RGI60-15.06881 \\
{$[33]$} & Rongbuk & 28.105 & 86.865 & RGI60-15.09991 \\
{$[34]$} & Gopal & 33.987 & 77.457 & RGI60-14.14383 \\
{$[34]$} & Stok & 33.968 & 77.47 & RGI60-14.14380 \\
{$[34]$} & Amda & 33.684 & 77.593 & RGI60-14.14431 \\
{$[34]$} & Karzok & 32.968 & 78.178 & RGI60-14.13571 \\
{$[34]$} & Mentok & 32.935 & 78.212 & RGI60-14.13576 \\
{$[34]$} & Urgos & 32.897 & 76.768 & RGI60-14.18483 \\
{$[34]$} & Panchi & 32.729 & 77.301 & RGI60-14.14909 \\
{$[34]$} & Shitidhar & 32.42 & 77.107 & RGI60-14.15723 \\
{$[34]$} & Batal & 32.364 & 77.603 & RGI60-14.16042 \\
{$[34]$} & Chhota Shigri & 32.266 & 77.529 & RGI60-14.15990 \\
{$[34]$} & Hamtah & 32.268 & 77.357 & RGI60-14.15536 \\
{$[34]$} & Beas Kund & 32.353 & 77.089 & RGI60-14.15265 \\
{$[35]$} & Chhota Shigri & 32.266 & 77.529 & RGI60-14.15990 \\
\hline & & & & \\
\hline
\end{tabular}


Supplementary Table 3: Literature values of englacial debris content (EDC) from mountain glaciers globally. Converted to $\%$ by volume using ice density of $915 \mathrm{~kg} \mathrm{~m}^{-3}$ and a rock density of $2700 \mathrm{~kg} \mathrm{~m}^{-3}$.

\begin{tabular}{ccccc}
\hline Reference & Glacier & Country & EDC & EDC (\% by volume) \\
\hline$[36]$ & d'Estelette & Italy & $0.072-332.88 \mathrm{~kg} \mathrm{~m}^{-3}$ & $0.0027-12$ \\
{$[37]$} & Khumbu & Nepal & $0.1-6.4 \%$ by volume & $0.1-6.4$ \\
{$[25]$} & G2 & Nepal & $10-865.6 \mathrm{mg} \mathrm{L}^{-1}$ & $0.0034-0.29$ \\
{$[38]$} & Muir & USA & $16.8+/-3 \mathrm{~kg} \mathrm{~m}^{-3}$ & $0.62+/-0.11$ \\
{$[38]$} & Margerie & USA & $8+/-8 \mathrm{~kg} \mathrm{~m}^{-3}$ & $0.3+/-0.3$ \\
{$[38]$} & Grand Pacific & USA & $2.5+/-2.4 \mathrm{~kg} \mathrm{~m}^{-3}$ & $0.093+/-0.089$ \\
{$[39]$} & Rakhiot & Pakistan & $2.13 \mathrm{~kg} \mathrm{~m}^{-3}$ & 0.079 \\
{$[40]$} & Kviarjokull & Iceland & $5.2 \mathrm{~kg} \mathrm{~m}^{-3}$ & 0.19 \\
{$[41]$} & Ayutor-2 & Uzbekistan & $0.02-0.33 \% \mathrm{by} \mathrm{weight}^{-3}$ & $0.0068-0.11$ \\
{$[42]$} & Djankuat & Russia & $0.12 \%$ by weight & 0.041 \\
{$[43]$} & Tasman & New Zealand & $0.028 \%$ by weight & 0.0095 \\
\hline
\end{tabular}


Supplementary Table 4: Errors and ranges of variables and parameters used in Monte Carlo simulations to calculate supraglacial debris thickness, with the references we estimated them from. We took all Monte Carlo samples from uniform distributions.

\begin{tabular}{ccc}
\hline Variable/parameter & Error/range & References \\
\hline$h_{s d}$ & $0.01-1 \mathrm{~m}$ & - \\
$T_{a}$ & $+/-1.5 \mathrm{~K}$ & {$[44-46]$} \\
$\Gamma$ & $+/-0.5 \mathrm{~K} \mathrm{~km}^{-1}$ & - \\
$k_{d}$ & $0.5-1.5 \mathrm{~W} \mathrm{~m}^{-1} \mathrm{~K}^{-1}$ & {$[2,47-49]$} \\
$\alpha_{d}$ & $0.1-0.4$ & {$[2,50-52]$} \\
$z_{0_{d}}$ & $0.005-0.06 \mathrm{~m}$ & {$[49,51,53,54]$} \\
\hline
\end{tabular}


Supplementary Table 5: Notation, description and units of variables and parameters described in Methods section of main text.

\begin{tabular}{|c|c|c|}
\hline Notation & Description & Unit \\
\hline$b$ & Specific mass balance & m w.e. $\mathrm{yr}^{-1}$ \\
\hline$h_{s d}$ & Supraglacial debris thickness & $\mathrm{m}$ \\
\hline$c_{1}$ & Free parameter & - \\
\hline$c_{2}$ & Free parameter & - \\
\hline$M$ & Sub-debris ice melt & m w.e. $\mathrm{hr}^{-1}$ \\
\hline$t$ & Time & $\mathrm{s}$ \\
\hline$\rho_{w}$ & Density of water & $\mathrm{kg} \mathrm{m}^{-3}$ \\
\hline$L_{f}$ & Latent heat of fusion of water & $\mathrm{J} \mathrm{kg}^{-1}$ \\
\hline$k_{d}$ & Thermal conductivity of debris & $\mathrm{W} \mathrm{m}{ }^{-1} \mathrm{~K}^{-1}$ \\
\hline$T_{s d}$ & Temperature of supraglacial debris & K \\
\hline$z$ & Depth within debris/elevation & $\mathrm{m}$ \\
\hline$\rho_{d}$ & Density of debris & $\mathrm{kg} \mathrm{m}^{-3}$ \\
\hline$c_{d}$ & Specific heat capacity of debris & $\mathrm{J} \mathrm{kg}^{-1} \mathrm{~K}^{-1}$ \\
\hline$S$ & Shortwave radiation flux & $\mathrm{W} \mathrm{m} \mathrm{m}^{-2}$ \\
\hline$L$ & Longwave radiation flux & $\mathrm{W} \mathrm{m} \mathrm{m}^{-2}$ \\
\hline$H$ & Sensible heat flux & $\mathrm{W} \mathrm{m} \mathrm{m}^{-2}$ \\
\hline$L E$ & Latent heat flux & $\mathrm{W} \mathrm{m}^{-2}$ \\
\hline$P$ & Heat flux due to precipitation & $\mathrm{W} \mathrm{m} \mathrm{m}^{-2}$ \\
\hline$\alpha_{d}$ & Albedo of debris surface & - \\
\hline$S \downarrow_{d i r}$ & Direct incoming shortwave radiation & $\mathrm{W} \mathrm{m}^{-2}$ \\
\hline$S \downarrow_{\text {dif }}$ & Diffuse incoming shortwave radiation & $\mathrm{W} \mathrm{m} \mathrm{m}^{-2}$ \\
\hline$S \downarrow_{b, d i r}$ & Direct incoming shortwave radiation normal to solar beam & $\mathrm{W} \mathrm{m}^{-2}$ \\
\hline$Z$ & Solar zenith angle & $\circ$ \\
\hline$Z^{\prime}$ & Surface slope & $\circ$ \\
\hline$A$ & Solar azimuth angle & $\circ$ \\
\hline$A^{\prime}$ & Surface azimuth & $\circ$ \\
\hline$S \downarrow_{r, d i r}$ & Direct incoming shortwave radiation of forcing dataset & $\mathrm{W} \mathrm{m} \mathrm{m}^{-2}$ \\
\hline$S \downarrow_{r}$ & Incoming shortwave radiation of forcing dataset & $\mathrm{W} \mathrm{m}^{-2}$ \\
\hline$S \downarrow_{r, d i f}$ & Diffuse incoming shortwave radiation of forcing dataset & $\mathrm{W} \mathrm{m}^{-2}$ \\
\hline$f_{\text {dif }}$ & Fraction of incoming shortwave radiation that is diffuse & - \\
\hline$f_{s v}$ & Sky-view factor & - \\
\hline$S \downarrow_{t e r}$ & Reflected incoming shortwave radiation from terrain & $\mathrm{W} \mathrm{m}^{-2}$ \\
\hline$\alpha_{t e r}$ & Albedo of terrain & - \\
\hline$\theta$ & Horizon angle & $\circ$ \\
\hline$\phi$ & Azimuth & $\circ$ \\
\hline
\end{tabular}


$L \downarrow_{s k y}$

$L \downarrow_{\text {ter }}$

$L \uparrow$

$L \downarrow r$

$\sigma$

$\varepsilon_{t e r}$

$T_{\text {ter }}$

$T_{a}$

$T_{a, r}$

$\Gamma$

$z_{r}$

$\varepsilon_{s d}$

$T_{s d, s}$

$\rho_{a}$

$c_{a, d r y}$

$u$

$C_{b t}$

$L_{v}$

$q_{a}$

$q_{s}$

$z_{\text {ref }}$

$u_{r}$

$k_{v k}$

$z_{0, d}$

$p_{a}$

$m_{a}$

R

$c_{a}$

$e_{a}$

RH

$e_{a, s a t}$

$c_{w}$

$r$

$T_{r}$

$V_{s d}$

$A_{s d}$

$\rho_{r}$

$q_{d s}$
Incoming longwave radiation from sky

Incoming longwave radiation from terrain

Outgoing longwave radiation

Incoming longwave radiation of forcing dataset

Stefan-Boltzmann constant

Emissivity of terrain

Temperature of terrain

Air temperature

Air temperature of forcing dataset

Air temperature lapse rate

Elevation of forcing dataset

Emissivity of supraglacial debris

Surface temperature of supraglacial debris

Density of air

Specific heat capacity of dry air

Wind speed

Bulk transfer coefficient

Latent heat of vaporisation of water

Specific humidity of atmosphere

Specific humidity at surface

Measurement height

Wind speed of forcing dataset

von Kármán constant

Surface roughness length of debris

Atmospheric pressure

Molecular weight of dry air

Gas constant

Specific heat capacity of air

Vapour pressure of atmosphere

Relative humidity

Saturated vapour pressure of atmosphere

Specific heat capacity of water

Precipitation rate

Temperature of precipitation

Volume of supraglacial debris

Area of supraglacial debris

Density of rock

Debris-supply rate
$\mathrm{W} \mathrm{m} \mathrm{m}^{-2}$

$\mathrm{W} \mathrm{m} \mathrm{m}^{-2}$

$\mathrm{W} \mathrm{m} \mathrm{m}^{-2}$

$\mathrm{W} \mathrm{m}^{-2}$

$\mathrm{W} \mathrm{m}{ }^{-2} \mathrm{~K}^{-4}$

K

K

K

$\mathrm{K} \mathrm{m}^{-1}$

m

K

$\mathrm{kg} \mathrm{m}^{-3}$

$\mathrm{J} \mathrm{kg}^{-1} \mathrm{~K}^{-1}$

$\mathrm{m} \mathrm{s}^{-1}$

$\mathrm{J} \mathrm{kg}^{-1}$

$\mathrm{m}$

$\mathrm{m} \mathrm{s}^{-1}$

m

$\mathrm{Pa}$

$\mathrm{kg} \mathrm{mol}^{-1}$

$\mathrm{J} \mathrm{K}^{-1} \mathrm{~mol}^{-1}$

$\mathrm{J} \mathrm{kg}^{-1} \mathrm{~K}^{-1}$

$\mathrm{Pa}$

$\%$

$\mathrm{Pa}$

$\mathrm{J} \mathrm{kg}^{-1} \mathrm{~K}^{-1}$

$\mathrm{m} \mathrm{s}^{-1}$

K

$\mathrm{m}^{3}$

$\mathrm{m}^{2}$

$\mathrm{kg} \mathrm{m}^{-3}$

$\mathrm{m} \mathrm{yr}^{-1}$ 


\begin{tabular}{ccc}
$A_{d s}$ & Debris-supply-slope area & $\mathrm{m}^{2}$ \\
$q_{e d}$ & Rate of emergence of englacial debris at glacier surface & $\mathrm{m} \mathrm{yr}^{-1}$ \\
$q_{e d, a}$ & Rate of emergence of englacial debris at active glacier surface & $\mathrm{m} \mathrm{yr}^{-1}$ \\
$A_{s d, a}$ & Area of active supraglacial debris & $\mathrm{m}^{2}$ \\
$q_{e d, i a}$ & Rate of emergence of englacial debris at inactive glacier surface & $\mathrm{m} \mathrm{yr}^{-1}$ \\
$A_{s d}$ & Area of inactive supraglacial debris & $\mathrm{m}^{2}$ \\
$Q_{s d, a \uparrow}$ & Volume flux of surface debris in to active glacier surface & $\mathrm{m}^{3} \mathrm{yr}^{-1}$ \\
$Q_{s d, a \downarrow}$ & Volume flux of surface debris out of active glacier surface & $\mathrm{m}^{3} \mathrm{yr}^{-1}$ \\
$\nabla Q_{s d, a}$ & Divergence of volume flux of surface debris in active part of glacier & $\mathrm{m} \mathrm{yr}^{-1}$ \\
$Q_{s d}$ & Volume flux of surface debris & $\mathrm{m}^{3} \mathrm{yr}^{-1}$ \\
$u_{s d}$ & Down-glacier component of surface velocity & $\mathrm{m} \mathrm{yr}^{-1}$ \\
$c_{e d, a b l}$ & Englacial debris content in ablation area & - \\
$M_{a}$ & Sub-debris melt rate of active part of glacier & $\mathrm{m} \mathrm{yr}^{-1}$ \\
$M_{i a}$ & Sub-debris melt rate of inactive part of glacier & $\mathrm{m} \mathrm{yr}^{-1}$ \\
$c_{e d, g l a c}$ & Englacial debris content of glacier & - \\
$\rho_{i, a b l}$ & Density of ice in ablation area & $\mathrm{kg} \mathrm{m}^{-3}$ \\
$\rho_{i, g l a c}$ & Density of glacier ice & $\mathrm{kg} \mathrm{m}^{-3}$ \\
\hline
\end{tabular}



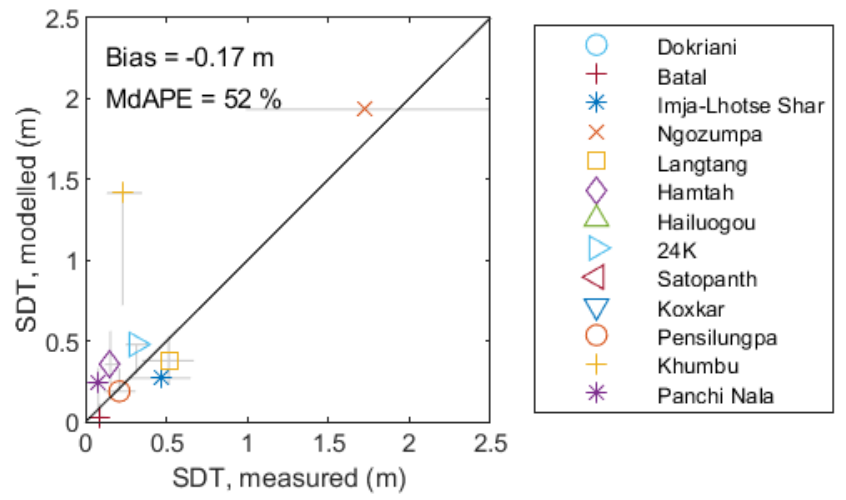

Supplementary Figure 1: Comparison of median modelled and measured supraglacial debris thickness (SDT) per study glacier, where latitude and longitude data of the SDT measurements are known. MdAPE is median absolute percentage error. Grey lines show the interquartile range. Here we note that we could only use a subsample of glaciers from Supplementary Table 1 in this validation because i) data for some of the glaciers in Supplementary Table 1 were unavailable from the authors, ii) we did not estimate SDT for some of the glaciers because they were surging or had an area smaller than $2 \mathrm{~km}^{2}$, as described in Methods. We note also that modelled and measured SDT appear quite different for Khumbu Glacier; modelled SDT is considerably greater than measured SDT, which affects the calculated values of bias and MdAPE. However, numerous ground-truth measurements made on the lower part of Khumbu Glacier are lower bounds on true SDT; pits were dug through the debris but the ice surface was not reached, as shown in Supplementary Figure 9. As such we were not able to use these measurements when calculating median measured SDT. If we had been able to use these measurements, modelled and measured SDT for Khumbu Glacier would likely be more similar. Measurements are from [2, 3, 6, 7, 9-13, 16, 27, 28, 55]. 

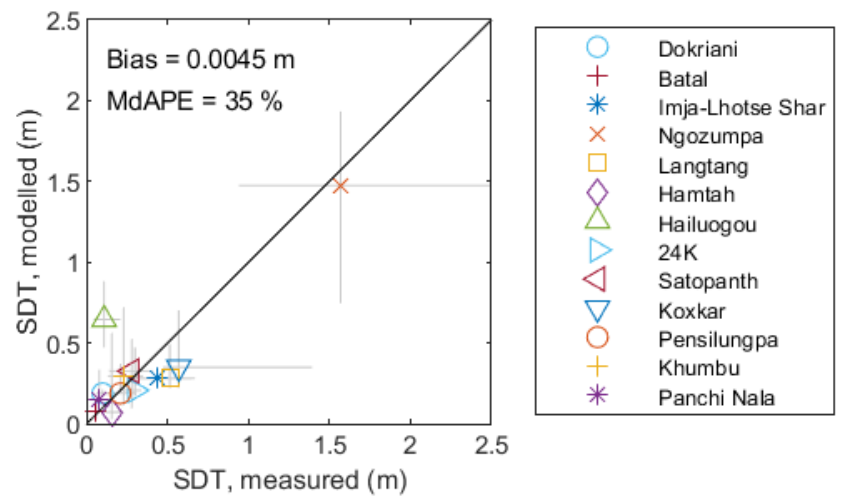

Supplementary Figure 2: Comparison of median modelled and measured supraglacial debris thickness (SDT) per study glacier within the elevation range of the SDT measurements. MdAPE is median absolute percentage error. Grey lines show the interquartile range. We show this figure in addition to Supplementary Figure 1 because for SDT measurements on some glaciers, latitude and longitude location data were unavailable, while elevation data were available. Note that the median measured value of SDT is different for some glaciers in Supplementary Figures 1 and 2 for the same reason. This is the case, for example, if some measurements on a glacier have latitude, longitude and elevation data, while other measurements have only elevation data. We note that modelled and measured SDT are quite different for Hailuogou Glacier because specific mass balance (SMB) for this glacier, from which SDT was calculated, was poorly constrained in the period 2000-2016 [56]. In turn, SMB here was poorly constrained because surface velocity from the ITS_LIVE product was poorly constrained, due to few optical satellite images as a result of frequent cloud cover. Measurements are from [2, 3, 6, 7, 9-13, 16, 27, 28, 55]. 


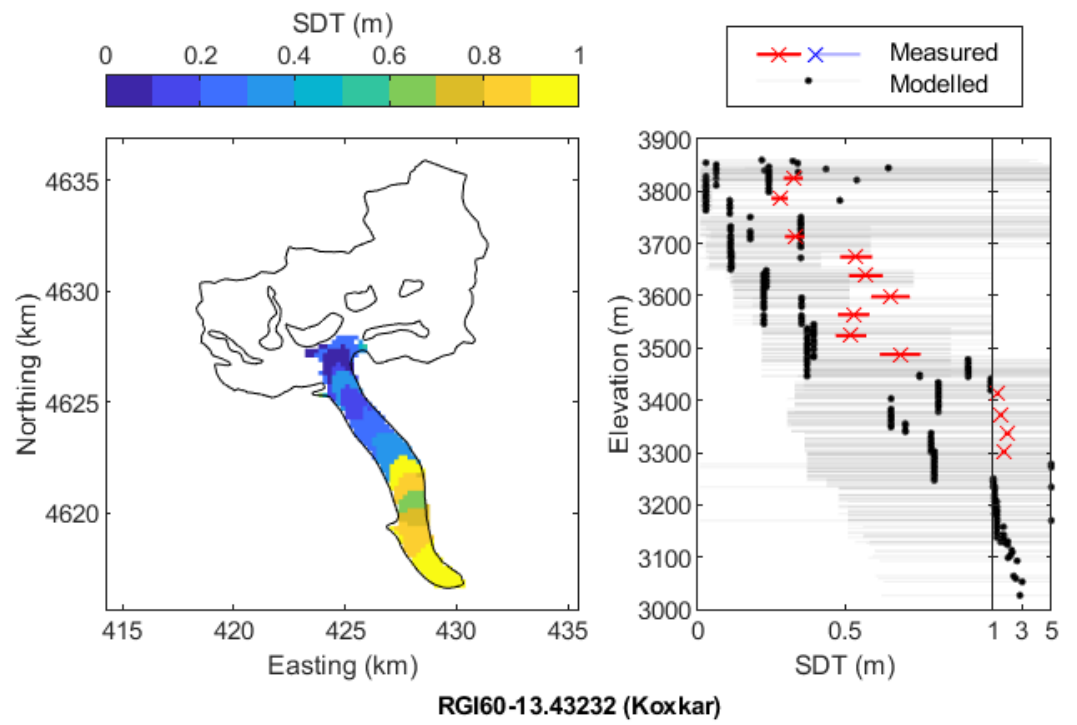

Supplementary Figure 3: Comparison of modelled and measured supraglacial debris thickness for Koxkar Glacier. Blue crosses indicate lower-bound measurements of SDT, where pits were dug through the debris but the ice surface below was not reached. We digitised measurements from [55]. 


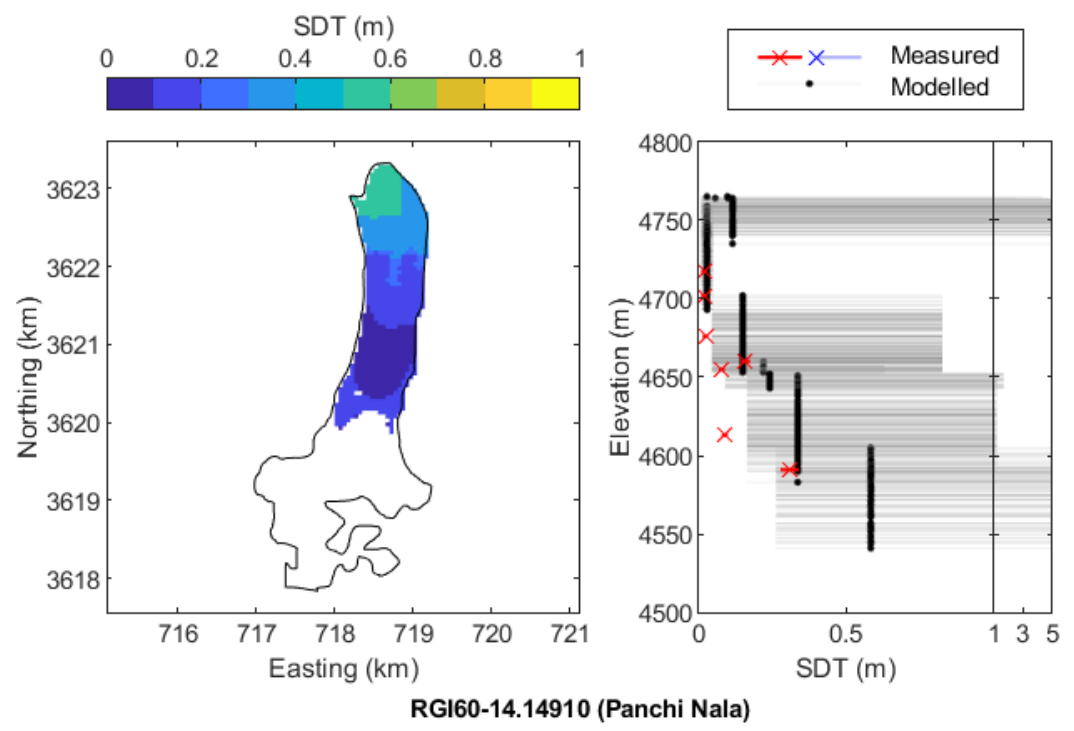

Supplementary Figure 4: Comparison of modelled and measured supraglacial debris thickness for Panchi Nala Glacier. Blue crosses indicate lower-bound measurements of SDT, where pits were dug through the debris but the ice surface below was not reached. We digitised measurements from [27]. 


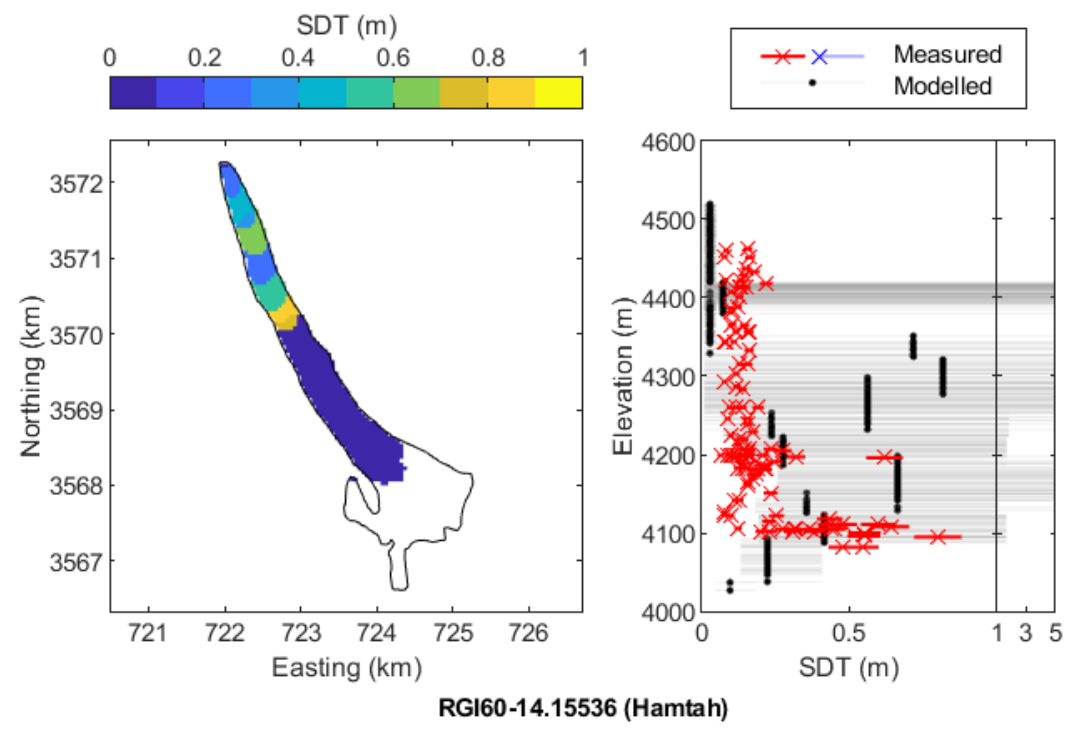

Supplementary Figure 5: Comparison of modelled and measured supraglacial debris thickness for Hamtah Glacier. Blue crosses indicate lower-bound measurements of SDT, where pits were dug through the debris but the ice surface below was not reached. Measurements are from [10]. 


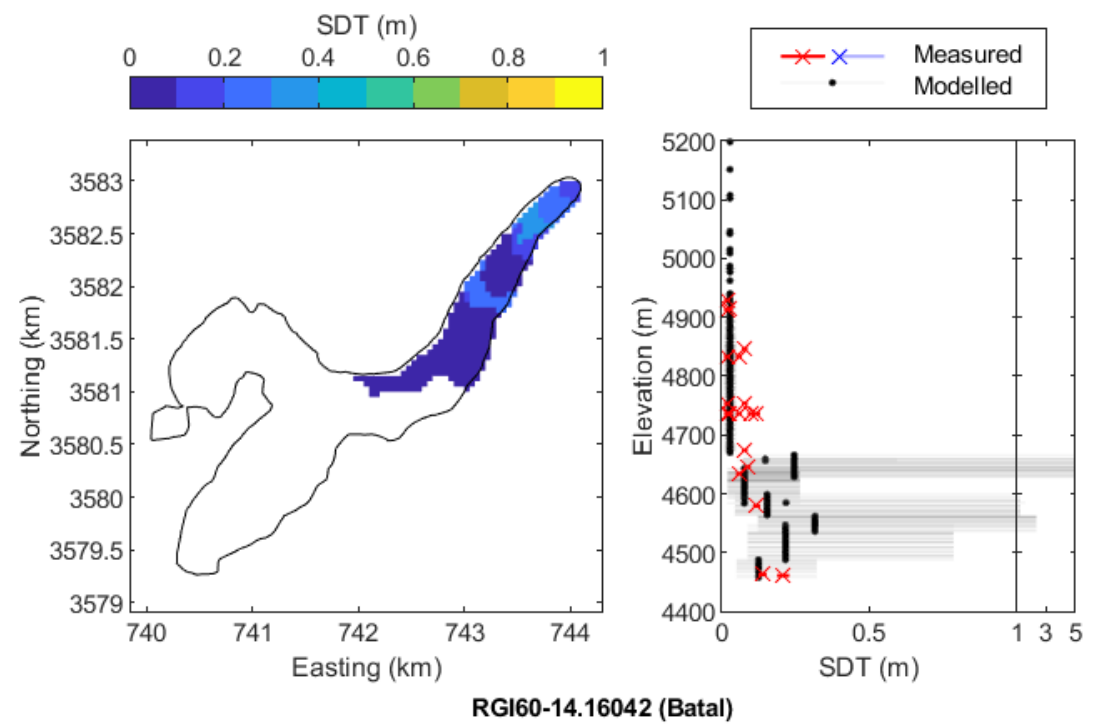

Supplementary Figure 6: Comparison of modelled and measured supraglacial debris thickness for Batal Glacier. Blue crosses indicate lower-bound measurements of SDT, where pits were dug through the debris but the ice surface below was not reached. Measurements are from [6]. 


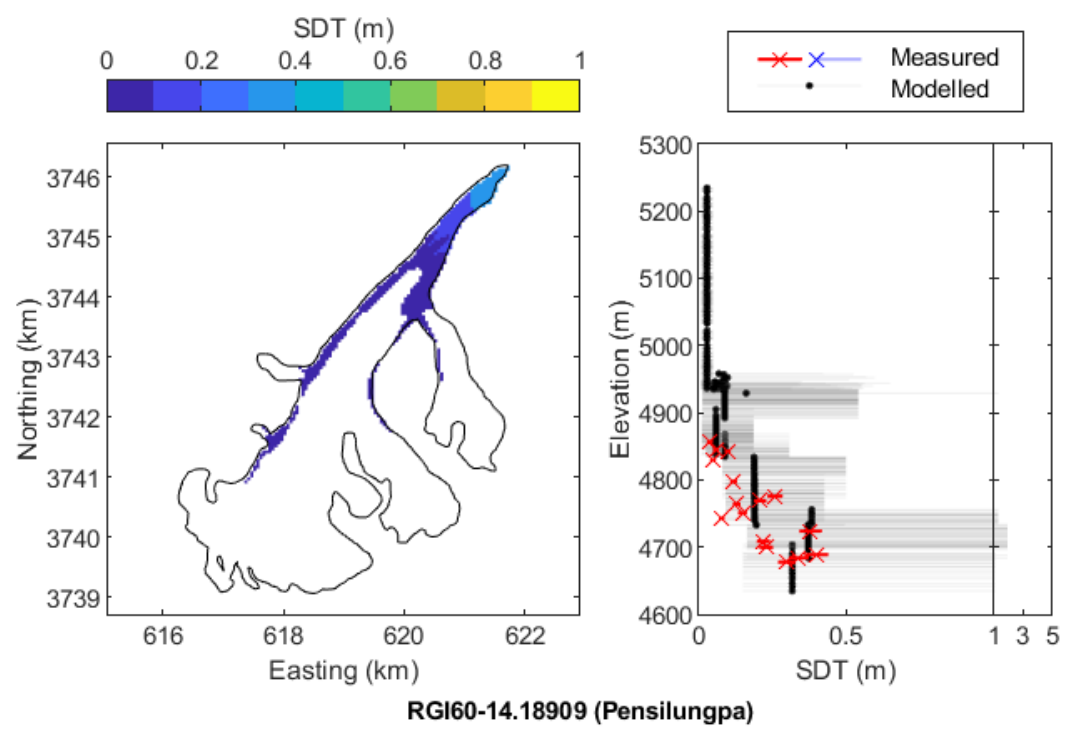

Supplementary Figure 7: Comparison of modelled and measured supraglacial debris thickness for Pensilungpa Glacier. Blue crosses indicate lower-bound measurements of SDT, where pits were dug through the debris but the ice surface below was not reached. Measurements are from [16]. 


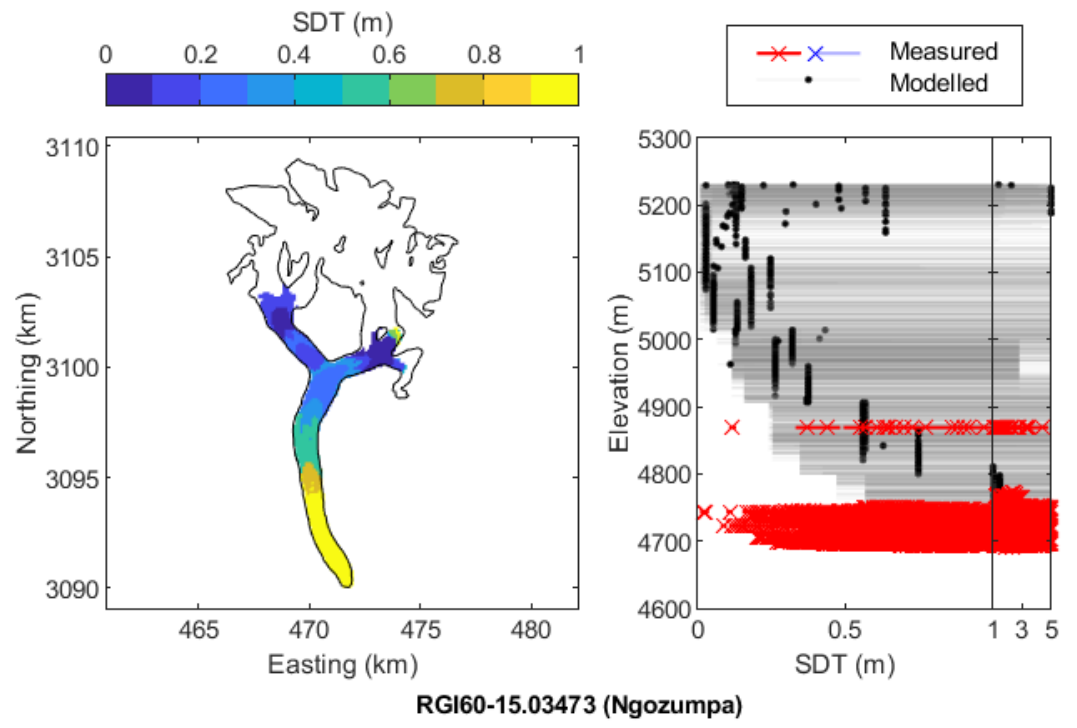

Supplementary Figure 8: Comparison of modelled and measured supraglacial debris thickness for Ngozumpa Glacier. Blue crosses indicate lower-bound measurements of SDT, where pits were dug through the debris but the ice surface below was not reached. Measurements are from [2,9]. 


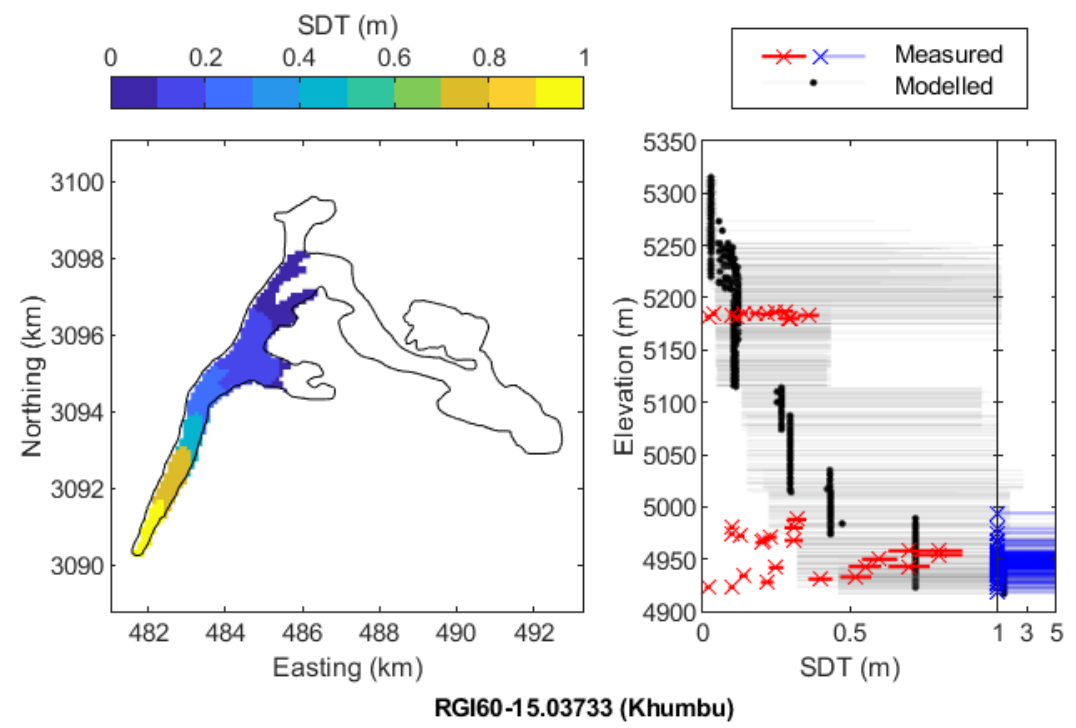

Supplementary Figure 9: Comparison of modelled and measured supraglacial debris thickness (SDT) for Khumbu Glacier. Blue crosses indicate lower-bound measurements of SDT, where pits were dug through the debris but the ice surface below was not reached. Measurements are from [28]. 


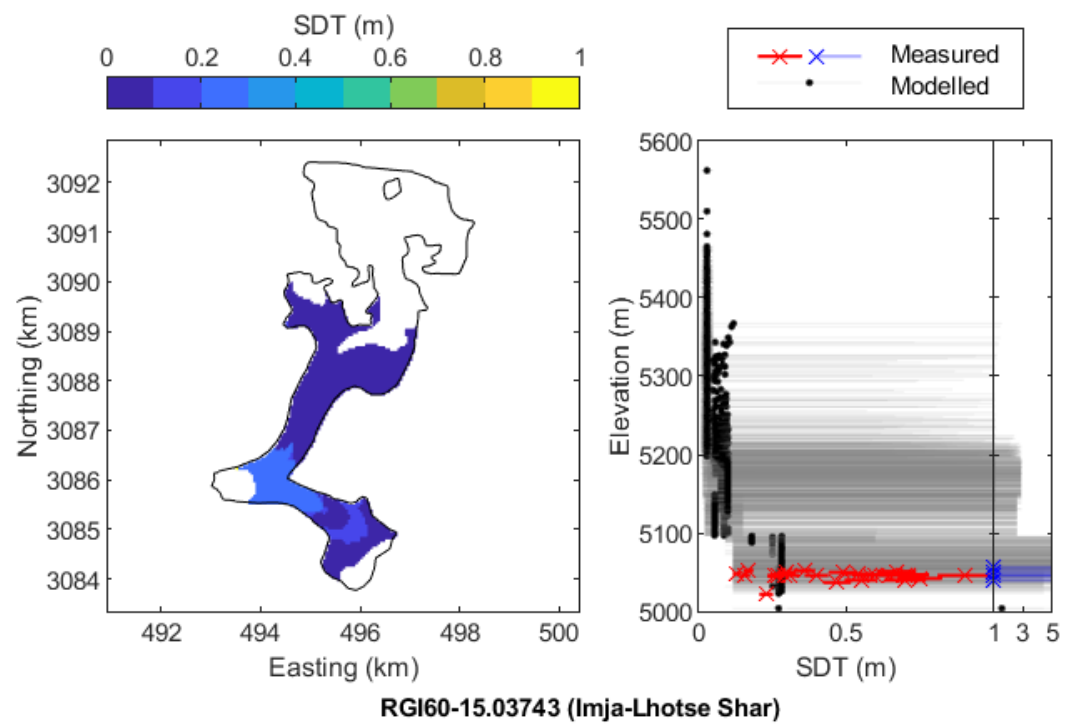

Supplementary Figure 10: Comparison of modelled and measured supraglacial debris thickness for Imja-Lhotse Shar Glacier. Blue crosses indicate lower-bound measurements of SDT, where pits were dug through the debris but the ice surface below was not reached. Measurements are from [7]. 


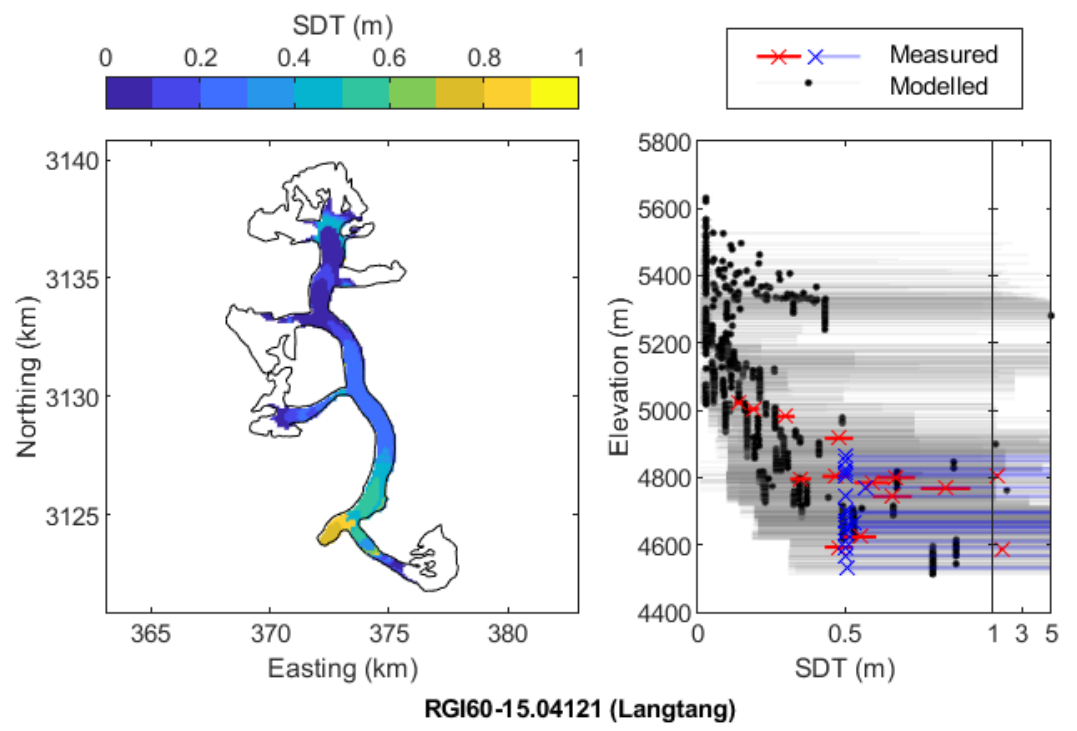

Supplementary Figure 11: Comparison of modelled and measured supraglacial debris thickness for Langtang Glacier. Blue crosses indicate lower-bound measurements of SDT, where pits were dug through the debris but the ice surface below was not reached. 


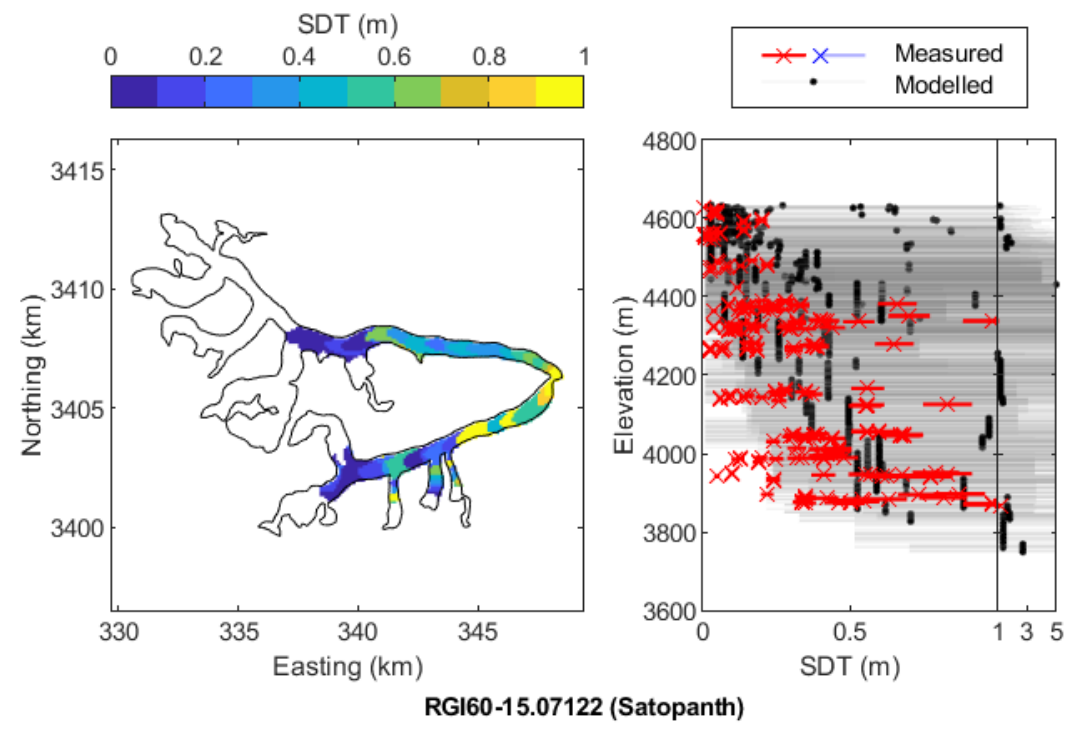

Supplementary Figure 12: Comparison of modelled and measured supraglacial debris thickness for Satopanth Glacier. Blue crosses indicate lower-bound measurements of SDT, where pits were dug through the debris but the ice surface below was not reached. Measurements are from [13]. 


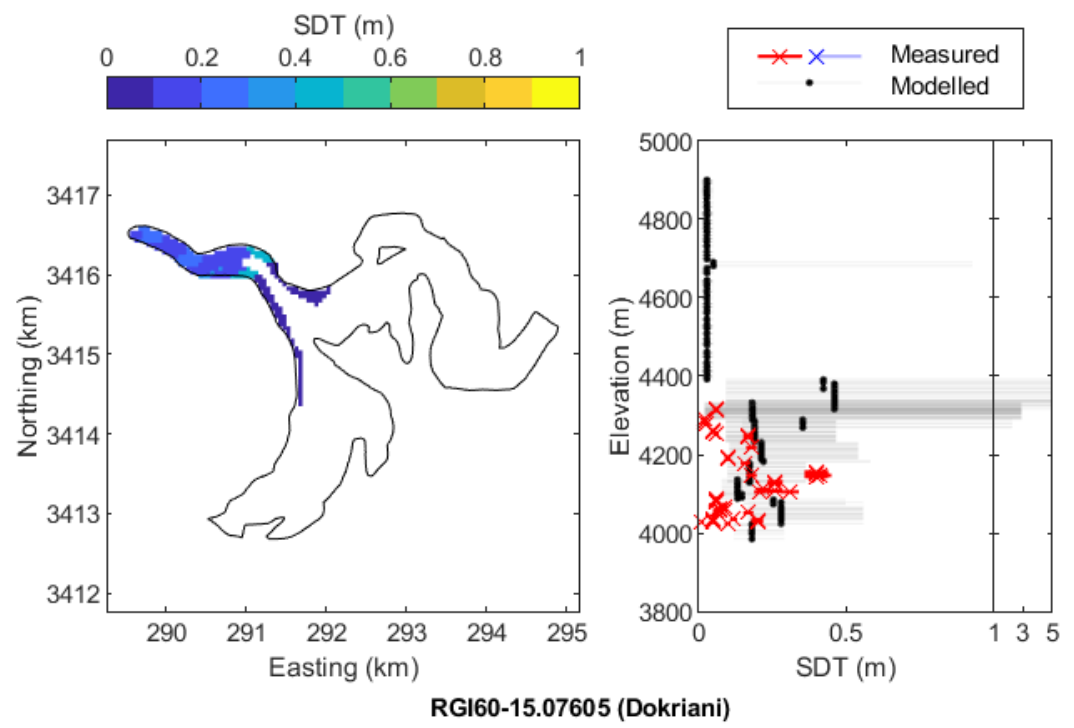

Supplementary Figure 13: Comparison of modelled and measured supraglacial debris thickness for Dokriani Glacier. Blue crosses indicate lower-bound measurements of SDT, where pits were dug through the debris but the ice surface below was not reached. Measurements are from [3]. 


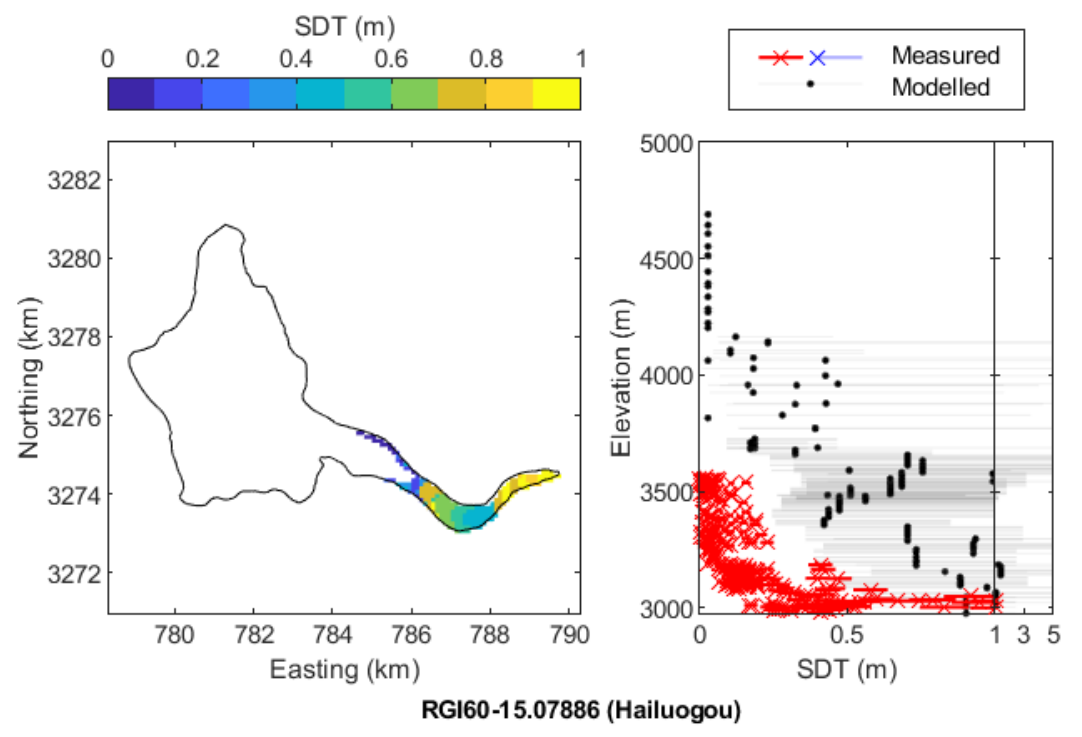

Supplementary Figure 14: Comparison of modelled and measured supraglacial debris thickness (SDT) for Hailuogou Glacier. Blue crosses indicate lower-bound measurements of SDT, where pits were dug through the debris but the ice surface below was not reached. As in the caption of Supplementary Figure 2, we note that modelled and measured SDT are quite different for Hailuogou Glacier because specific mass balance (SMB) for this glacier, from which SDT was calculated, was poorly constrained in the period 2000-2016 [56]. SMB here was poorly constrained because surface velocity from the ITS_LIVE product was poorly constrained, due to few optical satellite images as a result of frequent cloud cover. Specifically, observed surface velocity was too low, resulting in low modelled emergence velocity, low modelled SMB and high modelled SDT. We digitised measurements from [11]. 


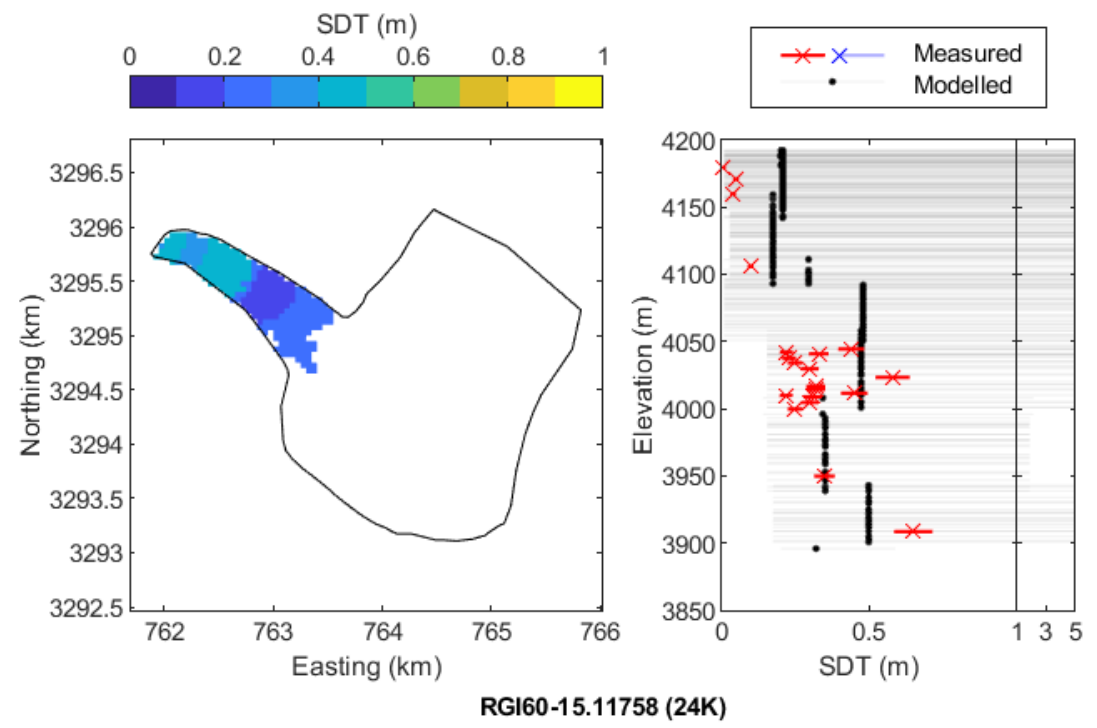

Supplementary Figure 15: Comparison of modelled and measured supraglacial debris thickness for 24K Glacier. Blue crosses indicate lower-bound measurements of SDT, where pits were dug through the debris but the ice surface below was not reached. We digitised measurements from [12]. 


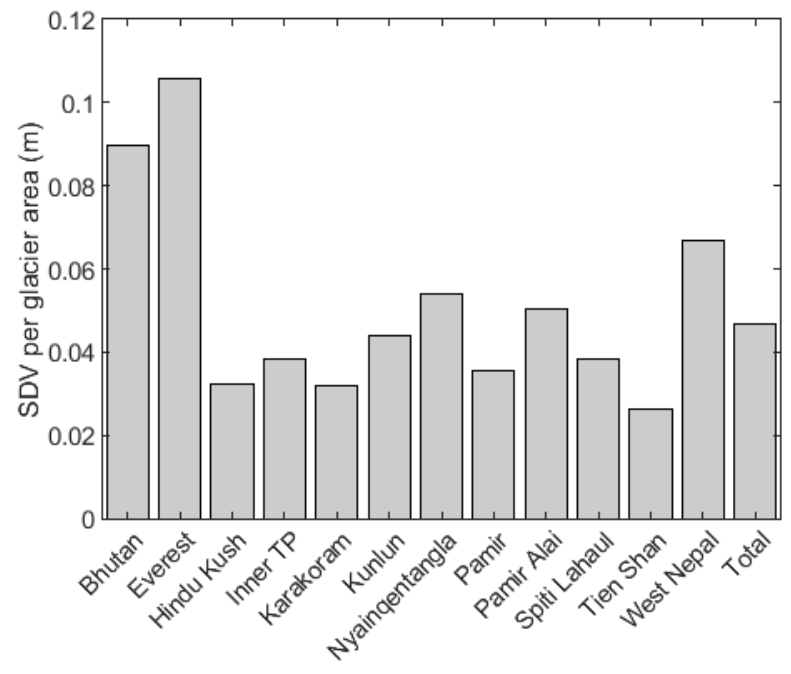

Supplementary Figure 16: Supraglacial debris volume (SDV) divided by glacier area per subregion in HighMountain Asia. 


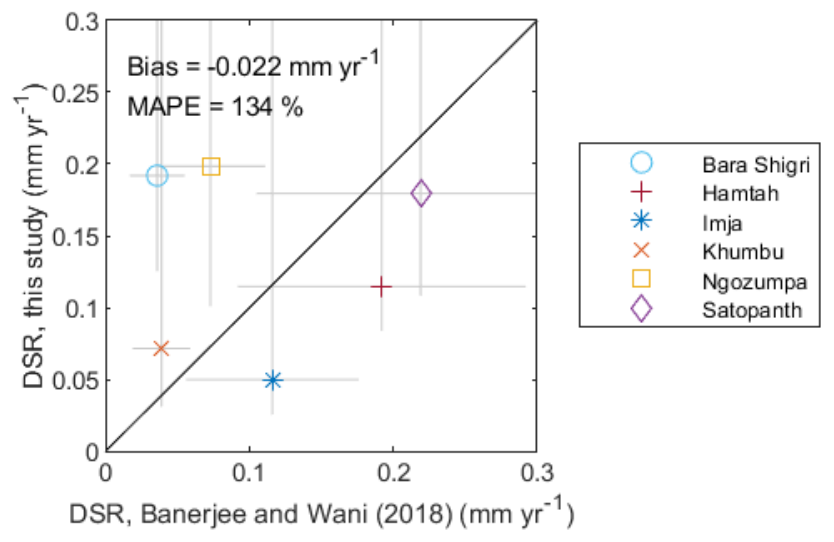

Supplementary Figure 17: Comparison of debris-supply rate (DSR) as modelled by [10] and DSR as modelled in this study. Grey lines indicate uncertainty. 


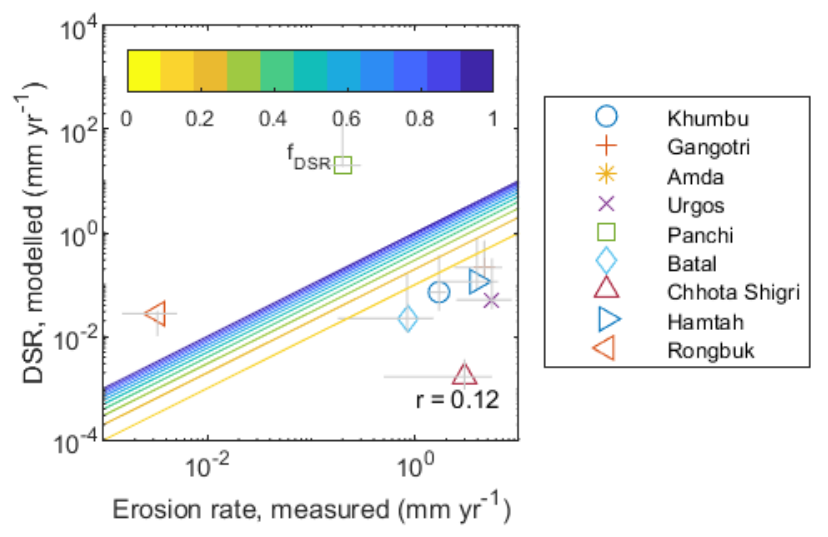

Supplementary Figure 18: Comparison of measured headwall-erosion rate from ${ }^{10} \mathrm{Be}$ cosmogenic nuclides $[29,32$ 35 ] and debris-supply rate (DSR) as modelled in this study. $\mathrm{f}_{\mathrm{DSR}}$ is the fraction DSR comprises of headwall-erosion rate. Grey lines indicate uncertainty. We note that DSR is typically around 4\% (median) of headwall-erosion rate. 


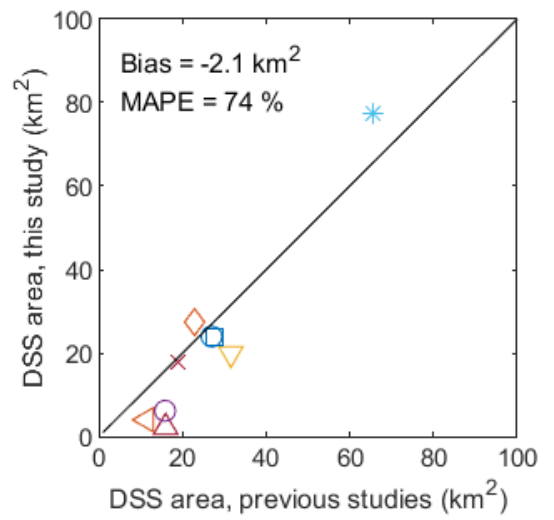

\begin{tabular}{|ll|}
\hline & Khumbu \\
+ & Gopal \\
$*$ & Stok \\
$\times$ & Amda \\
$\square$ & Karzok \\
$\square$ & Mentok \\
$\triangle$ & Panchi \\
$\square$ & Shitidhar \\
$\square$ & Batal \\
$\nabla$ & Chhota Shigri \\
$\bigcirc$ & Hamtah \\
+ & Beas Kund \\
$*$ & Bara Shigri \\
$\times$ & Imja \\
$\square$ & Khumbu \\
$\triangleright$ & Ngozumpa \\
\hline
\end{tabular}

Supplementary Figure 19: Comparison of debris-supply-slope areas of previous studies [10, 34, 57] with debrissupply-slope areas of this study. 


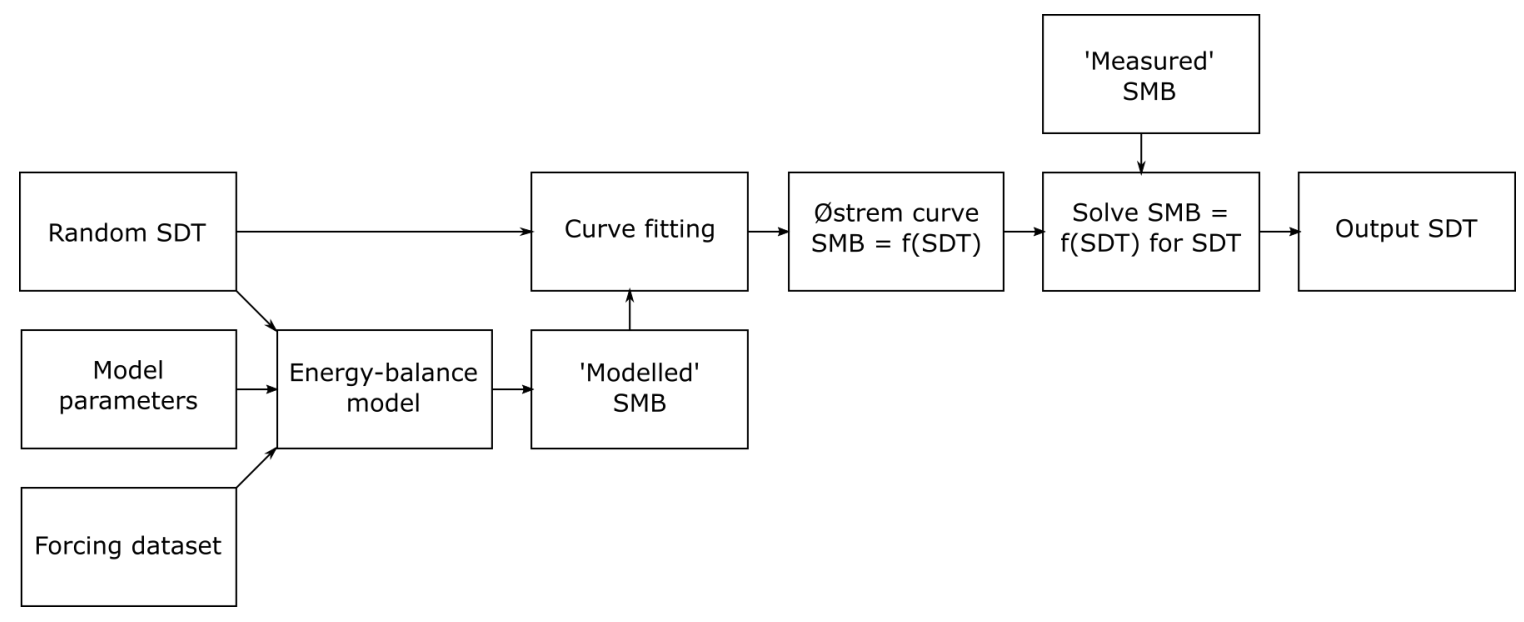

Supplementary Figure 20: Flow chart of supraglacial debris thickness (SDT) estimation method, where SMB is specific mass balance. 


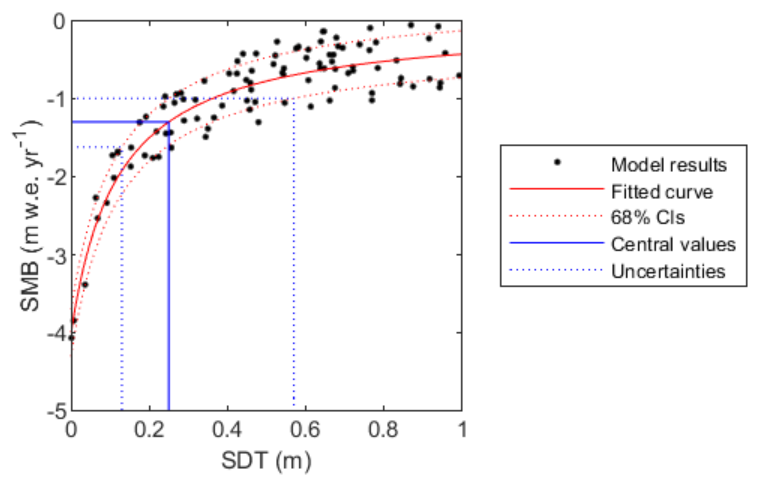

Supplementary Figure 21: Østrem curve fitting for supraglacial debris thickness (SDT) and uncertainty estimation. We used modelled values of specific mass balance (SMB), which we generated using random values of SDT, to fit Østrem curves such as the one in this figure. We then used these Østrem curves with the 'measured' SMB data of [56] to read off 'modelled' SDT and its uncertainty. 


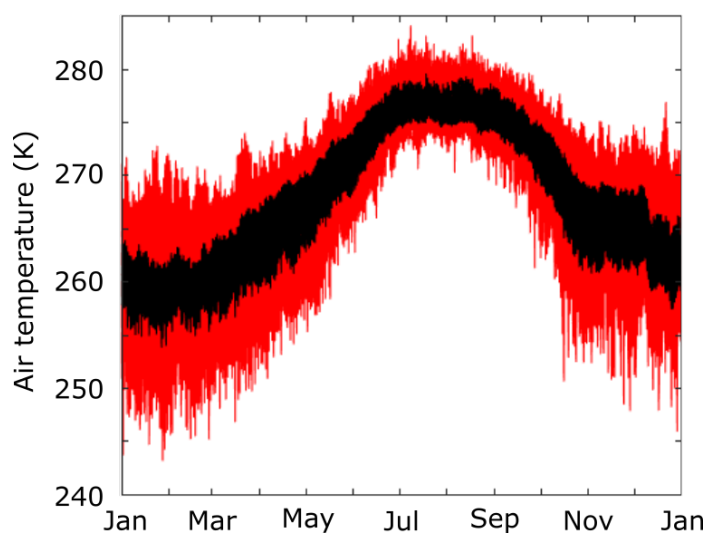

Supplementary Figure 22: An example mean year from the forcing dataset, showing air temperature on Langtang Glacier, Nepal. Red lines indicate individual years. The black line indicates the mean year. 


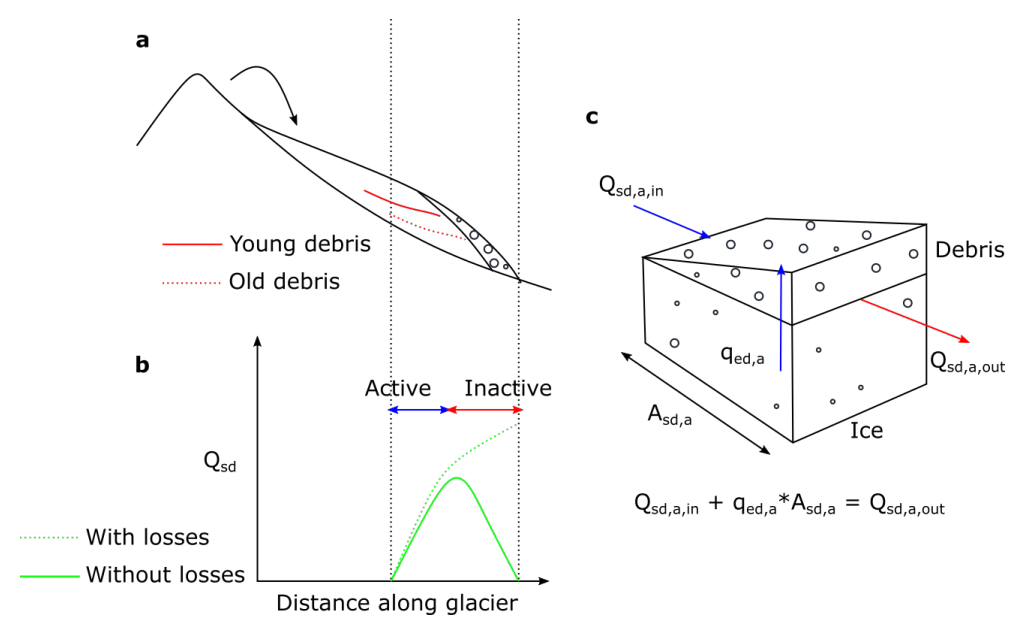

Supplementary Figure 23: Calculating debris-supply rate. a. Schematic showing process of debris supply to a glacier, with locations of young and old debris, after [58]. b. A surface-debris volume flux profile for a typical debris-covered glacier (with and without debris losses down-glacier due to surface-hydrology transport and moraine export), showing which parts of the glacier are active and which are inactive. c. Schematic of glaciersurface debris mass balance. 


\section{References}

1. RGI-Consortium. Randolph Glacier Inventory - A Dataset of Global Glacier Outlines: Version 6.0: Technical Report tech. rep. (Global Land Ice Measurements from Space, Colorado, USA, 2017).

2. Nicholson, L. \& Benn, D. I. Properties of natural supraglacial debris in relation to modelling sub-debris ice ablation. Earth Surface Processes and Landforms 38, 490-501 (2013).

3. Pratap, B., Dobhal, D., Mehta, M. \& Bhambri, R. Influence of debris cover and altitude on glacier surface melting: a case study on Dokriani Glacier, central Himalaya, India. Annals of Glaciology 56, 9-16 (2015).

4. Owen, L. A., Derbyshire, E. \& Scott, C. H. Contemporary sediment production and transfer in high-altitude glaciers. Sedimentary Geology 155, 13-36 (2003).

5. McCarthy, M., Pritchard, H., Willis, I. \& King, E. Ground-penetrating radar measurements of debris thickness on Lirung Glacier, Nepal. Journal of Glaciology 63, 543-555 (2017).

6. Patel, L. K., Sharma, P., Thamban, M., Singh, A. \& Ravindra, R. Debris control on glacier thinning-a case study of the Batal glacier, Chandra basin, Western Himalaya. Arabian Journal of Geosciences 9, 309 (2016).

7. Rounce, D. \& McKinney, D. Debris thickness of glaciers in the Everest area (Nepal Himalaya) derived from satellite imagery using a nonlinear energy balance model. The Cryosphere 8, 1317-1329 (2014).

8. Groos, A. R., Mayer, C., Smiraglia, C., Diolaiuti, G. \& Lambrecht, A. A first attempt to model region-wide glacier surface mass balances in the Karakoram: findings and future challenges. Geografia Fisica e Dinamica Quaternaria 40, 137-159 (2017).

9. Nicholson, L. I., McCarthy, M., Pritchard, H. D. \& Willis, I. Supraglacial debris thickness variability: impact on ablation and relation to terrain properties. The Cryosphere 12, 3719-3734 (2018).

10. Banerjee, A. \& Wani, B. A. Exponentially decreasing erosion rates protect the high-elevation crests of the Himalaya. Earth and Planetary Science Letters 497, 22-28 (2018).

11. Zhang, Y., Fujita, K., Liu, S., Liu, Q. \& Nuimura, T. Distribution of debris thickness and its effect on ice melt at Hailuogou glacier, southeastern Tibetan Plateau, using in situ surveys and ASTER imagery. Journal of Glaciology 57, 1147-1157 (2011).

12. Wei, Y., Tandong, Y., Baiqing, X. \& Hang, Z. Influence of supraglacial debris on summer ablation and mass balance in the 24K Glacier, southeast Tibetan Plateau. Geografiska Annaler: Series A, Physical Geography 92, 353-360 (2010).

13. Shah, S. S., Banerjee, A., Nainwal, H. C. \& Shankar, R. Estimation of the total sub-debris ablation from point-scale ablation data on a debris-covered glacier. Journal of Glaciology 65, 759-769 (2019).

14. Huang, L. et al. Estimation of supraglacial debris thickness using a novel target decomposition on L-band polarimetric SAR images in the Tianshan Mountains. Journal of Geophysical Research: Earth Surface 122, 925-940 (2017).

15. Dobhal, D., Mehta, M. \& Srivastava, D. Influence of debris cover on terminus retreat and mass changes of Chorabari Glacier, Garhwal region, central Himalaya, India. Journal of Glaciology 59, 961-971 (2013). 
16. Garg, P. K. et al. Stagnation of the Pensilungpa glacier, western Himalaya, India: causes and implications. Journal of Glaciology, 1-15 (2021).

17. Shroder, J. F., Bishop, M. P., Copland, L. \& Sloan, V. F. Debris-covered glaciers and rock glaciers in the Nanga Parbat Himalaya, Pakistan. Geografiska Annaler: Series A, Physical Geography 82, 17-31 (2000).

18. Soncini, A. et al. Future hydrological regimes and glacier cover in the Everest region: The case study of the upper Dudh Koshi basin. Science of the Total Environment 565, 1084-1101 (2016).

19. Hagg, W., Mayer, C., Lambrecht, A. \& Helm, A. Sub-debris melt rates on southern Inylchek Glacier, central Tian Shan. Geografiska Annaler: Series A, Physical Geography 90, 55-63 (2008).

20. Heimsath, A. M. \& McGlynn, R. Quantifying periglacial erosion in the Nepal high Himalaya. Geomorphol$\operatorname{ogy} 97,5-23(2008)$.

21. Giese, A., Arcone, S., Hawley, R., Lewis, G. \& Wagnon, P. Detecting supraglacial debris thickness with GPR under suboptimal conditions. Journal of Glaciology, 1-13 (2021).

22. Nakawo, M., Iwata, S., Watanabe, O. \& Yoshida, M. Processes which distribute supraglacial debris on the Khumbu Glacier, Nepal Himalaya. Annals of Glaciology 8, 129-131 (1986).

23. Mihalcea, C. et al. Ice ablation and meteorological conditions on the debris-covered area of Baltoro glacier, Karakoram, Pakistan. Annals of Glaciology 43, 292-300 (2006).

24. Wu, Z., Zhang, S. \& Liu, S. Optimal antenna of ground penetrating radar for depicting the debris thickness and structure of the Koxkar Glacier, Tianshan, China. Journal of Earth Science 24, 830-842 (2013).

25. Nakawo, M. Supraglacial debris of G2 glacier in Hidden Valley, Mukut Himal, Nepal. Journal of Glaciology 22, 273-283 (1979).

26. Wang, L., Li, Z. \& Wang, F. Spatial distribution of the debris layer on glaciers of the Tuomuer Peak, western Tian Shan. Journal of Earth Science 22, 528-538 (2011).

27. Shukla, A. \& Garg, P. K. Evolution of a debris-covered glacier in the western Himalaya during the last four decades (1971-2016): a multiparametric assessment using remote sensing and field observations. Geomorphology 341, 1-14 (2019).

28. Rowan, A. \& Gibson, M. Supraglacial debris thickness data from Khumbu Glacier, Nepal. Zenodo (2020).

29. Streule, M. J., Searle, M. P., Waters, D. J. \& Horstwood, M. S. Metamorphism, melting, and channel flow in the Greater Himalayan Sequence and Makalu leucogranite: Constraints from thermobarometry, metamorphic modeling, and U-Pb geochronology. Tectonics 29 (2010).

30. Seong, Y. B. et al. Rates of basin-wide rockwall retreat in the K2 region of the Central Karakoram defined by terrestrial cosmogenic nuclide 10Be. Geomorphology 107, 254-262 (2009).

31. Bhutiyani, M. Sediment load characteristics of a proglacial stream of Siachen Glacier and the erosion rate in Nubra valley in the Karakoram Himalayas, India. Journal of Hydrology 227, 84-92 (2000).

32. Orr, E. N., Owen, L. A., Saha, S. \& Caffee, M. W. Rates of rockwall slope erosion in the upper Bhagirathi catchment, Garhwal Himalaya. Earth Surface Processes and Landforms 44, 3108-3127 (2019). 
33. Owen, L. A. et al. Quaternary glaciation of mount everest. Quaternary Science Reviews 28, 1412-1433 (2009).

34. Orr, E. N., Owen, L. A., Saha, S., Hammer, S. J. \& Caffee, M. W. Rockwall slope erosion in the northwestern Himalaya. Journal of Geophysical Research: Earth Surface 126, e2020JF005619 (2020).

35. Scherler, D. \& Egholm, D. Production and transport of supraglacial debris: Insights from cosmogenic 10Be and numerical modeling, Chhota Shigri Glacier, Indian Himalaya. Journal of Geophysical Research: Earth Surface 125, e2020JF005586 (2020).

36. Kirkbride, M. P. \& Deline, P. The formation of supraglacial debris covers by primary dispersal from transverse englacial debris bands. Earth Surface Processes and Landforms 38, 1779-1792 (2013).

37. Miles, K. E. et al. Continuous borehole optical televiewing reveals variable englacial debris concentrations at Khumbu Glacier, Nepal. Communications Earth \& Environment 2, 1-9 (2021).

38. Hunter, L. E., Powell, R. D. \& Lawson, D. E. Flux of debris transported by ice at three Alaskan tidewater glaciers. Journal of Glaciology 42, 123-135 (1996).

39. Shroder Jr, J. F. in Himalaya to the Sea 134-141 (Routledge, 2002).

40. Swift, D. A., Evans, D. J. \& Fallick, A. E. Transverse englacial debris-rich ice bands at Kvıárjökull, southeast Iceland. Quaternary Science Reviews 25, 1708-1718 (2006).

41. Glazyrin, G. The formation of ablation moraines as a function of the climatological environment. IAHS Publication 104, 106-110 (1975).

42. Bozhinskiy, A., Krass, M. \& Popovnin, V. Role of debris cover in the thermal physics of glaciers. Journal of Glaciology 32, 255-266 (1986).

43. Kirkbride, M. The influence of sediment budget on geomorphic activity of the Tasman Glacier, Mount Cook National Park, New Zealand PhD thesis (University of Canterbury, 1989).

44. Betts, A. K., Chan, D. Z. \& Desjardins, R. L. Near-surface biases in ERA5 over the Canadian prairies. Frontiers in Environmental Science 7, 129 (2019).

45. Pelosi, A., Terribile, F., D’Urso, G. \& Chirico, G. B. Comparison of ERA5-Land and UERRA MESCANSURFEX reanalysis data with spatially interpolated weather observations for the regional assessment of reference evapotranspiration. Water 12, 1669 (2020).

46. Tetzner, D., Thomas, E. \& Allen, C. A validation of ERA5 reanalysis data in the Southern Antarctic Peninsula_Ellsworth land region, and its implications for ice core studies. Geosciences 9, 289 (2019).

47. Conway, H., Rasmussen, L. \& Nakawo, M. Summer temperature profiles within supraglacial debris on Khumbu Glacier, Nepal. IAHS Publication, 89-98 (2000).

48. Rowan, A. V. et al. Seasonally stable temperature gradients through supraglacial debris in the Everest region of Nepal, Central Himalaya. Journal of Glaciology 67, 170-181 (2021).

49. Rounce, D., Quincey, D. \& McKinney, D. Debris-covered energy balance model for Imja-Lhotse Shar Glacier in the Everest region of Nepal. The Cryosphere 9, 3503-3540 (2015). 
50. Miles, E. S., Steiner, J. F. \& Brun, F. Highly variable aerodynamic roughness length (z0) for a hummocky debris-covered glacier. Journal of Geophysical Research: Atmospheres 122, 8447-8466 (2017).

51. Quincey, D. et al. Evaluating morphological estimates of the aerodynamic roughness of debris covered glacier ice. Earth Surface Processes and Landforms 42, 2541-2553 (2017).

52. Kayastha, R. B., Takeuchi, Y., Nakawo, M. \& Ageta, Y. Practical prediction of ice melting beneath various thickness of debris cover on Khumbu Glacier, Nepal, using a positive degree-day factor. IAHS Publication 7182 (2000).

53. Inoue, J. \& Yoshida, M. Ablation and Heat Exchange over the Khumbu Glacier Glaciological Expedition of Nepal, Contribution No. 65 Project Report No. 4 on "Studies on Supraglacial Debris of the Khumbu Glacier". Journal of the Japanese Society of Snow and Ice 41, 26-33 (1980).

54. Takeuchi, Y., Kayastha, R. B. \& Nakawo, M. Characteristics of ablation and heat balance in debris-free and debris-covered areas on Khumbu Glacier, Nepal Himalayas, in the pre-monsoon season. IAHS Publication, 53-62 (2000).

55. Han, H.-d., Ding, Y.-j., Liu, S.-y. \& Wang, J. Regimes of runoff components on the debris-covered Koxkar glacier in western China. Journal of Mountain Science 12, 313-329 (2015).

56. Miles, E. et al. Health and sustainability of glaciers in High Mountain Asia. Nature Communications 12, 2868 (2021).

57. Barker, A. Glaciers, erosion and climate change in the Himalaya and St. Elias Range, SE Alaska PhD thesis (2016).

58. Wirbel, A., Jarosch, A. H. \& Nicholson, L. Modelling debris transport within glaciers by advection in a full-Stokes ice flow model. The Cryosphere 12, 189-204 (2018). 